\title{
Neuvostokalevalaisen runouden kasvu
}

\author{
Uusaiheinen kansanrunous Neuvosto-Karjalassa
}

\author{
Joonas Ahola
}

$\mathrm{N}$ euvostokarjalaiset runonlaulajat tuottivat neuvosto-oloja kuvaavaa ja neuvostoideologiaa propagoivaa kalevalamittaista runoutta lähinnä 1930-luvun lopun ja 1950luvun alkupuolen välillä. Neuvosto-oloissa tuotettuun perinteestä kumpuavaan ja perinteeseen viittaavaan "uusperinteeseen" viitataan Venäjällä termillä novina (ven. новина, mon. новины), joka on 1930-luvun uudissanana johdettu mennyttä aikaa kuvaavaan eeppiseen suulliseen runoon viittaavien sanojen старина (> suom. tarina) tai былина pohjalta (Oinas 1973, 49-50). Suomessa siitä on käytetty neutraalia käännöstä "uusaiheinen runous" (Alin 1988, 42). Karjalassa uusaiheisen runouden ilmaisumuodoksi vakiintui kalevalamitta, ja koska se muotoutui tavallaan aiemman runonlaulutradition jatkoksi tai haaraksi, käytän uusaiheisen runouden kalevalamittaisesta ryhmästä nimitystä neuvostokalevalainen runous.

Neuvostokalevalainen runous jää jonnekin perinteisen ilmaisutavan tai -muodon ja ideologisesti asennoituneen sisällön välille. Neuvostoliiton hallinnon suhtautumista kansallisten kulttuurien muotoihin kuvasi 1920-luvulta alkaen vuosikymmenien ajan hokema "muodoltaan kansallinen, sisällöltään sosialistinen kulttuuri", jota Josif Stalin määrittelee teoksessaan Марксизм и национально-колониальный вопрос (Marxismi ja kansallis-kolonialistinen kysymys, 1934). Hänen mukaansa sosialistisen ideologian välittäminen kielellisesti ja kulttuurisesti moninaisin tavoin oli Neuvostoliiton monikulttuurisessa ympäristössä välttämätön välivaihe matkalla tilanteeseen, jossa neuvostokansalaiset jakaisivat sosialistisen ideologian ohella yhteisen ilmaisutavan. Tässä välivaiheessa sosialistinen viesti tuli siis välittää paikallisesti ymmärrettävällä ilmaisutavalla. (Ks. Grenoble 2003, 41-50; Kangaspuro 2000, 231-233.) Neuvostokalevalaisen runouden kohdalla asia ei ollut aivan näin yksioikoinen, mutta runonlaulua saattoi pitää tällaisena paikallisena ruohonjuuritason ilmaisutapana. Toisaalta sillä oli symbolinen lisämerkitys myös suomalaisten kansalliseepokseen Kalevalaan liittyvänä perinteisenä ilmaisumuotona, millä oli arvonsa Neuvosto-Karjalalle eräänlaisena poliittisena rintamavyöhykkeenä Neuvostoliiton ja Suomen välillä. Neuvostokalevalaista runoutta on käsitelty Suomessa joissakin artikkeleissa (Leino 1975; Kaukonen 190; Alin 1988) ja ne ovat olleet aiheena ainakin yhdelle opinnäytteelle (Alin 1984), mutta neuvostokalevalaisen runouden taustoja ei ole toistaiseksi avattu perusteellisemmin. Neuvostokarjalaiset artikkelit ja julkaisut tarjoavat kuvauksia niiden sisällöistä ja laulajista, mutta näitä julkaisuja vaivaa neuvostoliittolaisille julkaisuille tyypillinen ideologinen painotus (esim. Jevsejev 1940, 1941, 1947, 1953, 1960; Gran 1947, 1954; Jaakkola 1949; Rugojev 1958, 1959, 1965; Timonen 1984; Belovanova ja Razumova 1947). 
Tarkastellessani tässä artikkelissa neuvostokalevalaisen runouden kasvun historiallista kontekstia käsittelen muun muassa seuraavia kysymyksiä: Mitä pontimia neuvostokalevalaisen runouden synnylle Neuvosto-Karjalassa oli, ja millaiseksi se muotoutui? Kuinka tämä tekstilaji liittyi suulliseen perinteeseen? Mikä oli runonlaulajien osuus neuvostokalevalaisen runouden synnyssä, ja millaiseksi runojen tekijyys lopulta määrittyy? Kuinka nämä piirteet neuvostokalevalaisen runouden kasvussa vaikuttavat itse runojen luentaan?

Tutkimusaineistoni koostuu sekä julkaistuista että julkaisemattomista runoista, joista jälkimmäiset ovat peräisin Karjalan Tiedekeskuksen kansanperinnearkistosta. Tarkastelen runoja osana kirjallisuudelle, runoudelle ja kansanperinteelle miellettyjä tehtäviä paitsi Neuvosto-Karjalassa, myös Neuvostoliitossa laajemmin. Sitä myötä esimerkkirunojen valikoinnissa ja tulkinnoissani korostuu se, kuinka runot heijastavat historiallista kontekstiaan. Toisaalta luen runoja perinteisen suullisen runon konventioita vasten, mikä osaltaan johtaa neuvostokalevalaisten runojen yhtäläisyyksien ja erojen korostumiseen suhteessa traditioon, josta ne muotonsa puolesta nousivat. Vaikka pyrin tulkitsemaan aineistoa sen kontekstia vasten, tulkintani kumpuavat omasta ajastani ja omasta taustastani folkloristina. Tämä artikkeli jatkaa aiemman artikkelini (Ahola 2020) pohdintoja, sillä käsittelin siinä erilaisia kansanperinteeseen ja Kalevalaan neuvostokarjalaisessa julkisessa keskustelussa liittyneitä diskursseja.

\section{Kalevalamitta varhaisessa neuvostokarjalaisessa taiderunoudessa}

Petroskoissa ja Leningradissa julkaistiin jo Neuvostoliiton varhaisvaiheista alkaen suomenkielisiä lehtiä, joissa ilmestyi myös runoutta ja kirjallisuusaiheisia artikkeleita. Varsinaisia kirjallisuuslehtiä olivat leningradilainen Soihtu ja petroskoilainen Puna-Kantele, johon Soihtu yhdistettiin vuonna 1930. Vuodesta 1932 lehden nimenä oli Rintama, 1938-1940 Karelija ja sen jälkeen Punalippu. Jonkin verran saman aihepiirin tekstejä julkaistiin sanomalehdissä. Niistä keskeisin oli 1923 alkaen ilmestynyt Punainen Karjala, joka ilmestyi karjalankielisenä 1938-1940 nimellä Sovetskoi Karelija ja sen jälkeen nimellä Totuus. Lehdistö oli alusta asti kommunistisen puolueen ohjauksessa ja tiukan sensuurin alaisuudessa, mikä merkitsi kaiken julkaisemisen aktiivista poliittista valvontaa. (Ylikangas 2004, 134-138, 262-266, 313, 405-408; Ahola 2020, 6-7.)

Kalevalamitalla oli arvo runouden muotona Neuvostoliiton suomenkielisissä kirjailijapiireissä 1920-luvulta alkaen. Kalevalamittaa oli käytetty Suomessa karelianistisessa taiderunoudessa, ehkä kuuluisimpana esimerkkinä Eino Leinon Helkavirsiä (1903-1916). Karelianismi liittyi Suomessa sisällissodan jälkeen 1920-luvulla nationalismiin, mutta Neuvostoliitossa kalevalamitan käyttö sai erilaisia merkityksiä: yhtäältä Karjalaan vahvasti assosioituna paikallisena suullisen taiteen muotona, toisaalta Suomen kansallisen symbolin Kalevalan mitallisena muotona. Neuvostoliitossa suomalaiset kirjailijat käyttivät kalevalamittaa siis paitsi paikallisena "koloriittina" eli erityispiirteenä (ks. Kurki 2006, 255), myös ottivat aiemman kansallisen identiteettinsä symbolin uuteen käyttöön sosialistista ideologiaa korostavassa runoudessa ja taivuttivat sillä tavoin kansallista identiteettiään luokkaidentiteetin suuntaan. Leningradilaisessa Soihtu-kulttuurilehdessä julkaistussa Ragnar Ruskon (1928) runossa "Kenpä virren viertäjäksi" ovat esimerkiksi seuraavat säkeet: 


\author{
Täynnä salot sankareita \\ tunturit sodantuhoja, \\ Karjalassa kaatuneita \\ eestä nuoren Neuvostolan. \\ Siellä veljet vainajina \\ odottavat laulajaansa...
}

Kaksiosaisen runon ensimmäinen osa kuvaa salomaiden rauhassa lepääviä vallankumouksen uhreja, toinen neuvostojärjestelmän tuomaa modernisaatiota ja vaurautta. Runon mukaan molemmat asiat ansaitsevat "virren viertäjää, muistosanain saattajaa".

Petroskoilaisen kirjallisuuslehden Puna-Kanteleen ensimmäinen numero (1/1928) esitteli paitsi perinteistä kansanrunoutta, myös kalevalamittaa mukailevia taiderunoja, joita julkaistiin lehdessä sittemmin säännöllisesti. Esimerkiksi Oskar Johanssonin (1930) runo "Väkevien voimalla" kuvaa metsätöitä urheiden metsureiden sotaisan dramaattisena kamppailuna puujättiläisiä vastaan. Runo kuvaa työtä seuraavin säkein:

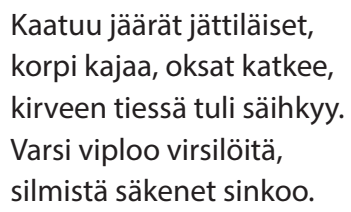

Esimerkkirunoissa Neuvosto-Karjalan sosialistiselle identiteetille keskeisimmille osa-alueille, vallankumouksen jälkeisen sodan sankaritöille ja työponnistuksille sosialistisen yhteiskunnan rakentamiseksi, annetaan kalevalamitalla ja herooiseen maailmaan kurottavalla sanastolla myyttistä hohtoa. Kalevalamittaisen runon konventioista ovat tunnistettavissa keskeisimmät, siis nelipolvinen trokeemitta, säkeensisäinen alkusointu ja paralleelikertaus, kun taas suurimmat poikkeamat perinteisestä runosta ovat metaforin ilmaistun sisällön lisäksi lähinnä sanastossa ja kankeassa säerakenteessa'.

Kalevala on monesti runojen selkeä esikuva. Esimerkiksi Suomessa asuneen työläiskirjailija Toivo Raidan runossa "Rintamatoverusten juhla" (Raita 1928), joka julkaistiin Leningradin suomalaisten Soihtu-lehdessä, lainataan Kalevalasta kokonaisia säkeitä ja säepareja, joihin Raita liittää sujuvasti poliittisia merkityksiä:

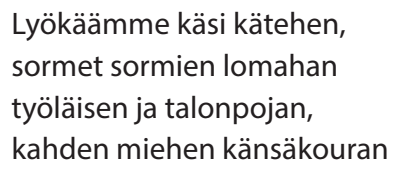

Tällä tavalla hän antaa Kalevalasta tutuille säkeille (runo 1, säkeet 21-22) uusia merkityksiä, kyseisessä tapauksessa propagandassa tuohon aikaan viljellyn kehotuksen työläisten ja talonpoikien liittoon Neuvostoliitossa näiden keskinäisen epäluulon sijaan, ks. kuva 1.

1 Säkeistä valtaosa on tasasäkeitä, ja kalevalakielen vähemmän kohosteiset konventiot, kuten pitkien ja lyhyiden pääpainollisten tavujen sijoittuminen tiettyihin metrisiin asemiin, ilmenevät vain vaihtelevasti. 


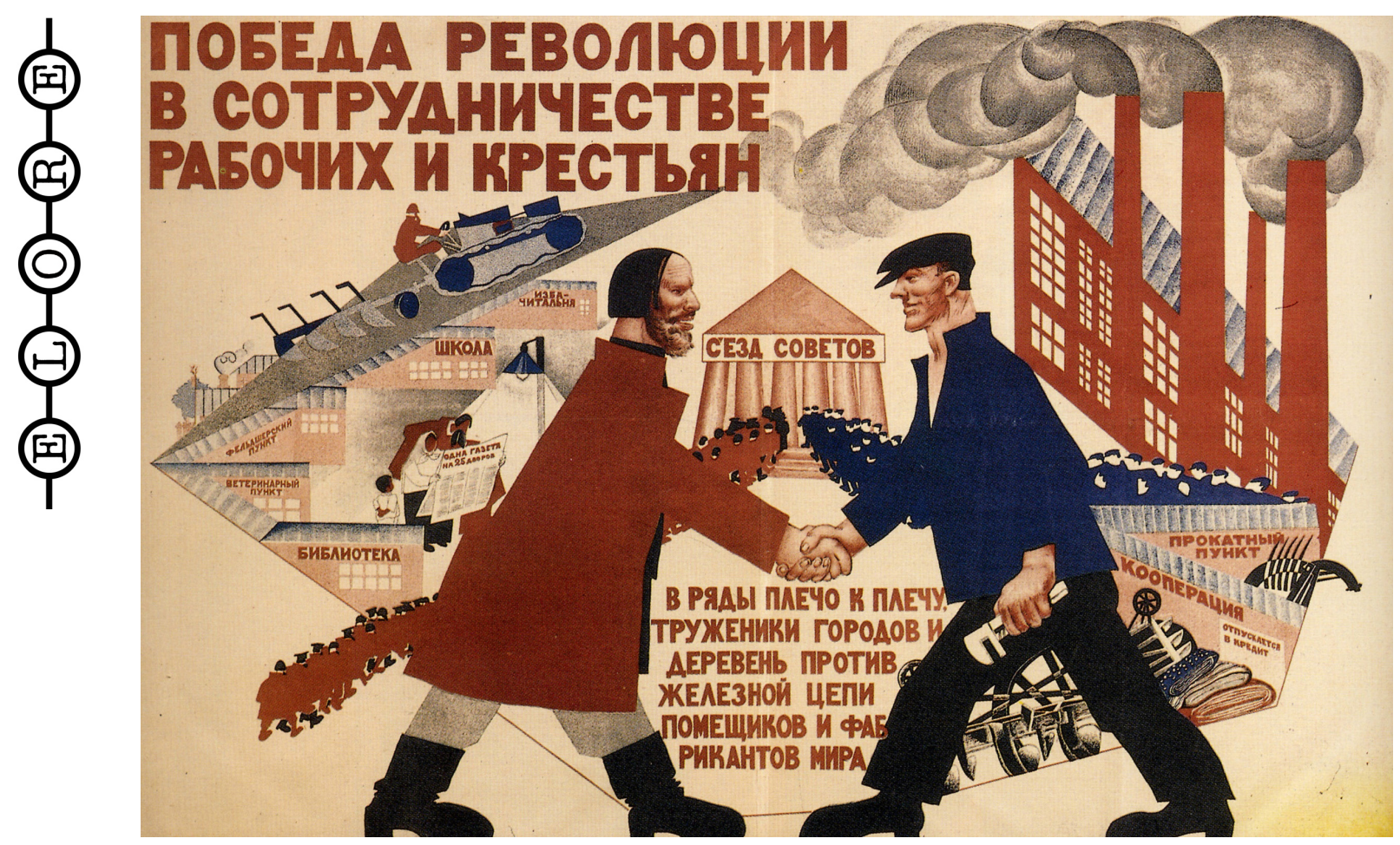

Kuva 1. Михаил Михайлович Черемных 1925: «Победа революции в сотрудничестве рабочих и крестьян». Lähde: https://artchive.ru/artists/1935 Mikhail Mikhajlovich Cheremnykh/works/507186 Pobeda revoljutsii v sotrudnichestve rabochikh i krest\%27jan V rjady plecho $\mathrm{k}$ plechu truzheniki gorodov $\mathrm{i}$ dereven $\% 27$ protiv zheleznoj tsepi pomeschikov i fabrikantov mira

Jalmari Virtasen runossa "Ristiäiset" vuodelta 1928 (Virtanen 1956, 190-194) Karjala on kuvattu kaltoin kohdelluksi tytöksi, joka tulee ukonilmaksi kuvatun sisällissodan melskeissä raskaaksi "suurelle neuvostosoturille" ja synnyttää Kontupohjan kaupungin:

syntyi lapsonen, lajia suurinta ei, pienintäkään, vaan on sankarin sukua.

Kalevalamitta ja Kalevalasta tutut yksittäiset säkeet toimivat tässä "luonnonmyytilliselle" allegorialle paitsi motivoivana taustana, myös paikallisena kotoperäisenä muotona. Paikallisuuden korostamisen ohella (esim. Kyllönen 1929) perinteistä asua tavoittavien runojen aihepiirit liikkuvat työn eetoksessa (esim. Johansson 1930; Rusko 1930) ja jopa kuplettimaisessa Suomen sisällissodan tapahtumien kuvauksessa (Rusko 1929).

Leningradilaiset suomalaisrunoilijat käyttivät kalevalamittaa ennen muuta omaan vähemmistökansallisuuteensa liittyvän sävyn ja poliittisen ylevyyden tavoittamiseksi, minkä avulla oli samalla mahdollista luoda suomalaisten suuntaan merkityksiä Kalevalan ja siihen liittyvien porvaris-Suomen arvojen kautta. Karjalassa perinteen muoto liittyi lisäksi paikallisuuden esiin nostamiseen, kuten Jalmari Virtasen runoissa. Karjalaisten oma kirjallisuus alkoi vasta hakea muotoaan. 


\section{Kalevalamitta karjalaisen kotoperäisen kirjallisuuden luomisessa}

Neuvosto-Karjalan kotoperäisen kirjallisen kulttuurin pohja oli ohut, perinteistä suullista runoutta ja kerrontaa lukuun ottamatta, minkä keskushallinto koki 1920-luvun loppuun tultaessa puutteeksi (Jalava 1990, 38-39). Karjalan kirjailijayhdistys KAPP:n ensimmäisessä konferenssissa vuonna 1929 pohdittiinkin, kuinka karjalainen runous voisi kehittyä kansallisesti omintakeisempaan suuntaan. Yhdeksi keinoksi ehdotettiin kalevalamitassa pysyttäytymistä. Tämä sai kuitenkin vastaansa kiivasta kritiikkiä, koska sitä pidettiin suomalaisten aluelaajennuspyrkimyksiä tukevana. (Ylikangas 2004, 161-163.) Kalevalamitan liittyminen suomalaiseen nationalismiin jäi neuvostokarjalaisissa keskusteluissa vähäisempään rooliin vuoden 1934 jälkeen, kun Maksim Gorki nosti kansanperinteen malliksi neuvostoliittolaiselle kirjallisuudelle proletariaatin kollektiivisena äänenä arvovaltaisessa puheessaan neuvostokirjailijoiden liiton ensimmäisessä konferenssissa (ks. Oinas 1973, 46-48; Olson 2004, 39-40). Gorki määritteli kansanperinteen kansanjoukkojen luovaksi ilmaisuksi ja rinnasti sen kirjallisuuteen, mikä samalla merkitsi sitä, että yksilöiden luomat tekstit saatettiin lukea kansanperinteeseen. Kun uusien ilmausten luojat edustivat työläisjoukkoja, he edustivat samalla folklorea luovaa yhteiskuntaluokkaa, ja samalla logiikalla mikä vain, mitä he loivat, oli potentiaalisesti folklorea (народное творчество, 'kansantaidetta', 'kansanperinnettä') (Olson 2004, 41).

Gorkin puhe oli poliittinen kannanotto 1930-luvun alussa vallinneisiin neuvostoliittolaisen folkloristiikan keskusteluihin, joissa otettiin etäisyyttä aiempiin tutkimuksiin folkloren universaaleista formaaleista piirteistä (formalismi) ja joissa pohdittiin folkloren liittymistä esitysympäristönsä ja esittäjiensä sosiaalisiin tekijöihin. Samoissa keskusteluissa oli lisäksi nostettu esiin paitsi folkloren haitallisuus sensuurin saavuttamattomissa olevana julkisena puheena, myös sen käyttökelpoisuus propagandan ja agitaation tarpeisiin. (Howell 2015, 261-272.) Vuoden 1934 jälkeen nousikin karjalaisissa kirjailijapiireissä esiin puheenvuoroja kansanrunouden tallentamiseksi ja julkaisemiseksi malliksi ja opiksi karjalaisille kirjailijoille (esim. E. P. 1934; J.V. 1935).

Kansanperinne ja suullinen kerronta muodostuivat keskeiseksi osaksi karjalaisen kirjallisuuden kuvaa (Jalava 1990, 40). Esimerkiksi Armas Äikiä korostaa vuonna 1941 välirauhan aikana perinteiden vaalimisen tärkeyttä Karjalan kirjallisuuden kehittymiselle: "Kirjallisuusperintömme on saanut henkistä ravintoa suuresta kansallisrunoelmastamme Kalevalasta, pitänyt esikuvinaan sen sammon takojia, kyntäjiä ja kylväjiä, sen mahtavia laulumiehiä. Kehittääksemme tasavaltamme kirjallisuutta on meidän vaalittava tämän kansankirjallisuutemme perinteitä." (Punalippu 2/1941, 112.) Vaikka Äikiä lukeekin tämän sitaatin jälkeen kansanrunouden ja suomalaisen kirjallisuushistorian merkkiteokset yhtäläisesti karjalaisen kirjallisuuden pohjalla vaikuttavaksi traditioksi, Kalevalalla ja sen heijastamalla suullisella runoudella oli erityinen arvo neuvostokarjalaisen kotoperäisen kirjallisuuden luomisessa.

\section{Kalevalamittaisten mallien valikointi ja julkaisu}

Kalevalamittaista kansanrunoutta julkaistiinkin neuvostokarjalaisissa kulttuurilehdissä ja sanomalehdissä 1920-luvun lopulta alkaen suhteellisen säännöllisesti. Esimerkiksi kirjallisuuslehti Puna-Kanteleessa niitä oli ensimmäisestä numerosta lähtien vuonna 1928 (ks. Jalava 1990, 38-39; 111). Kaikkea kansanperinnettä ja kansanrunoutta ei katsottu kuitenkaan 
yhtäläisesti mallikelpoiseksi sisällöiltään, vaan julkaistavien tekstien tuli osallistua sosialistiseen rakennustyöhön siinä kuin kaikkien muidenkin julkaisujen.

Vähemmistökansallisuuksiin ja kansallismielisyyteen oli suhtauduttu epäilevästi Neuvostoliitossa sen perustamisesta asti. Vähemmistökansallisuuksien kulttuureita suvaittiin ja jopa kannustettiin 1920-luvulla ja 1930-luvun alussa, mutta niiden esittely ei saanut olla ristiriidassa Neuvostoliiton luokkalähtöisen yhtenäisyysideologian kanssa (Slezkine 1994, 451; Mihelj ja Senjkovic 2010, 111-112). 1930-luvun kuluessa vähemmistökulttuurien asema heikkeni edelleen (Shelestyuk 2019). Folkloristit ja etnografit liikkuivat paljon vähemmistökansojen parissa ja työnsä puolesta nostivat esiin kulttuurien ja historian erityispiirteitä, jotka eivät usein sopineet ideologiseen konsensukseen, mistä he saivat usein julkista arvostelua osakseen (Olson 2004, 36-37). Vaikka 1930-luvun puolimain vähemmistökansallisuuksien kulttuurillisia mestariteoksia nostettiin näkyvästi esiin, kuten Kalevala vuonna 1935 (Slezkine 1994, 446-448), julkaistavaksi aiottu kansanperinne oli valikoitava huolella.

Esimerkiksi Josef Sykiäinen (1940) toteaa, että "kansantarujen kertojien" tuotoksista tulee julkaista "vain täyspainoiset, jättäen syrjään huonot". Tämän arvioinnin perusteet eivät käy kannanotosta suoraan ilmi, vaikka siinä kehotetaan myös osoittamaan kertojille heidän "virheensä". Nikolai Jaakkola (1949) sen sijaan tuo selkeästi esiin poliittis-ideologiset arviointiperusteet kirjoittaessaan kymmenen vuotta myöhemmin (kun stalinistinen poliittinen sensuuri oli vahvimmillaan ja avoimimmillaan), että vaikka kansanrunous edustaa pohjimmiltaan ideologisesti hyväksyttäviä arvoja ja vaikka runot soveltuvat hyvin koristamaan "karjalais-suomalaisten runoilijain sisällöltään sosialistisia tuotteita karjalaisen aitouden värivivahteilla", myös kansanrunoudessa "on löydettävissä meille vieraita ja kelpaamattomia takapajuisia aineksia. Siksi neuvostokirjailijain ja -runoilijain on kaikkeen kulttuuriperintöön, myöskin muinaisajan kansantietoisuuteen, suhtauduttava kriitillisesti ja luovasti." (Jaakkola 1949, 41.)

Vaikka Kalevalaa pidettiin ainakin julkisessa keskustelussa yleisesti kansanrunoutta edustavana tekstinä (ks. Ahola 2020), Stalinismin huippuaikana, Uuden Kalevalan juhlavuonna 1949, Neuvosto-Karjalan päämiehenä toiminut ja Kalevalaan monissa kirjoituksissaan kantaa ottanut O. W. Kuusinen näki tarpeelliseksi julkaista Kalevalasta oman editionsa. Hän antaa teoksen johdannossa ohjeet tekstin ideologisesti oikeaoppiselle luennalle, mutta perustelee Kalevalan runoista tekemäänsä valikointia lähinnä luettavuudella:

[Kalevalan] täydellisen laitoksen ohella on kuitenkin tarpeen lyhennetty kokoelma eli valikoima, jonka pohjalla nykyajan lukijain olisi helpompi eläytyä Kalevalan runouteen. Kokemus on näet osoittanut, että monelle lukijalle tuottaa Kalevalan runouden omaksumisessa vaikeuksia sekä runojen pituus että niihin liitettyjen loitsujen, laulujen ja häävirsien paljous, joka useissa kohdin katkaisee eepillisen kertomuksen etenemisen. (Kuusinen 1949, xxviii.)

Toimitustyössään Kuusinen järjesteli runoja myös jossain määrin uudelleen ja jätti pois "liiat loitsutemput" sekä "sellaisia kertosäkeitä, jotka nykyajan lukijasta tuntuvat liioilta ja merkityksettömiltä." Täydentäviä säkeitä Kuusinen kertoo löytäneensä Lönnrotin toimittamasta lyhennetystä Kalevalasta, siis ilmeisesti Koulu-Kalevalasta. (Kuusinen 1949, xxix.) Kuusisen julkaisu noudatti siis periaatteita, joita kansanrunouden julkaisussa peräänkuulutettiin muutenkin - tai toimi periaatteille Kuusisen auktoriteetin siivittämänä esimerkkinä. 
Vasta folkloristien julkaisemat ideologisesti oikeaoppiset aineistot tarjosivat legitimiteettiä heidän työlleen (Kalkun ja Oras 2018, 44), mikä epäilemättä myös asetti odotuksia sen suhteen, millaista aineistoa heidän odotettiin löytävän ja julkaisevan. Julkaistuun folkloreen suhtauduttiin siis kuten muihinkin julkaisuihin: sen tuli osallistua sosialistisen yhteiskunnan rakentamiseen ja noudattaa poliittisen sensuurin määrittelemiä linjoja (ks. Miller 1990, 11-14).

\section{Folklore propagandan välineenä Neuvostoliitossa}

Valikoivan julkaisun ja päämäärätietoisen tulkinnan ohella itse teksteihin vaikuttaminen nähtiin Neuvostoliitossa yhdeksi keinoksi lisätä kansanperinnejulkaisujen poliittista oikeaoppisuutta jo 1930-luvun alussa. Jo ennen vallankumousta alkaneet akateemiset keskustelut kirjallisuuden vaikutuksesta folkloreen ja tämän vaikutuksen hyväksyminen osaksi folkloren olemusta pohjustivat uusaiheisen runouden syntyä ja ohjaamista Stalinin aikaan (Ziolkowski 2013, 52). Esimerkiksi Sokolovin veljekset torjuivat 1920-luvulla romantiikan vaaliman idean kollektiivisesti kehkeytyneestä perinteestä nostaen esiin laulajien oman kokemuspiirin vaikutuksen bylinoiden sisältöihin ja jättivät folkloren ja taidekirjallisuuden välisen suhteen epäselväksi myös osoittamalla, kuinka kerronta-aines liikkui suullisen perinteen ja kirjoitetun kirjallisuuden välillä molempiin suuntiin. (Ziolkowski 2013, 49-51, 82-83.) Toisaalta 1930-luvun alussa asetettiin folkloren olemus reliikkinä, jäänteenä aiemmilta kulttuurisilta kausilta, vastakkain uuden erityisesti urbaanin folkloren kanssa (Howell 2015, 261 264). Juri Sokolov $(1966,14-15)$ kiteytti vastakkainasettelun vuonna $1934^{2}$ synteesiksi, jonka mukaan folklore on "kaiku menneisyydestä mutta samalla nykyajan ääni", mikä mahdollisti esimerkiksi sen, että uudenaikaisten aiheiden esittäminen vanhakantaisessa muodossa oli miellettävissä folkloreksi (ks. Ziolkowski 2013, 84). Jyrkkä kansanperinteen kahtiajako reliikkeihin ja nykyperinteeseen näkyi vielä neuvostokarjalaisen seutututkimuksen kansanperinteen keruukutsussa $1935^{3}$, jossa uutta ja vanhaa elämäntapaa heijastavat kulttuuriset ilmiöt jaetaan seuraavasti:

\footnotetext{
Kalevalan 100-vuotisjuhlan yhteydessä ansaitsee suurta huomiota kansan luomisen tuotteiden - kolhoosilaisten ja työläisten laulujen ja rallatusten, kansalaissotaa koskevien kertomusten muistiinkirjoittaminen, uusien elämäntapojen kuvaaminen. Samanaikaisesti on kirjoitettava muistiin myöskin kaikki kansan luomat 'muinaiset' tuotteet - runot, eepilliset kansanlaulut, laulut, sadut, ennustukset, tarut, vanhat elintavat ja muu kansanrunousaineisto. (Punainen Karjala 12.5.1935.) ${ }^{4}$
}

Folkloren poliittisessa potentiaalissa tunnistettiin vuoden 1931 neuvostoliittolaisissa folkloristikonferensseissa sekä uhkia että mahdollisuuksia sosialismille. Siinä kun folklorea pidettiin yhtäältä alempia luokkia alistavien vanhakantaisten ideologioiden välityskanavana ja täten haitallisena proletariaatin itsetietoisuudelle. Toisaalta folkloressa nähtiin mahdollisuuksia propagandan ja agitaation välittämiselle. (Howell 2015, 265-271.) Folkloren aiheuttamien vaarojen hallitsemiseksi ja hyötyjen valjastamiseksi nostettiin esiin tarve puuttua folkloren tuottamisprosesseihin: tutkijoilla katsottiin olevan syytä osallistua tutkimansa folkloren tuottamiseen, jotta aineisto soveltuisi julkaistuna agitaatioon (Howell 2015, 272;

2 Sokolov julkaisi tekstin ensinnä vuonna 1934 artikkelissa "Природа фольклора и проблемы фольклористики." Литературный критик 12: 127-151. Artikkeli toimii avauslukuna hänen merkittävässä folkloristiikan oppikirjassaan Русский фольклор (1938). Teos käännettiin englanniksi vuonna 1950 (Sokolov 1966).

3 Karjalan Toimeenpaneva Keskuskomitea pyrki jalkauttamaan karjalaiset oman alueensa luonnon- ja kulttuuririkkauksien kartoitukseen "seutututkimuksen" nimissä.

4 Kaikki alleviivaukset esimerkeissä ovat tämän artikkelin kirjoittajan tekemiä. 
Ziolkowski 2013, 85). Juri Sokolovin mukaan folkloren esittäjien ja tuottajien luovan prosessin ohjaaminen ideologisesti oikeaoppiseen suuntaan oli myös oikeutettua jopa määritelmänmukaisesti spontaanin ja kollektiivisen kansanperinteen kohdalla, koska ohjaaminen tapahtuu samasta yhteiskuntaluokasta (työtätekevien joukosta) käsin kuin missä folkloren luominen ja esittäminenkin tapahtuu; ohjaus on siis ikään kuin tradition sisältä päin tapahtuvaa ja sellaisena luonnollista (Sokolov 1966, 25-27; ks. Miller 1990, 7).

Ajatus ihmisten ajatuksiin vaikuttamisesta kansanperinteen välityksellä nostettiin esiin myös suomenkielisten kirjailijoiden keskuudessa. Yrjö Savolainen kirjoittaa artikkelissaan "Inkeriläisestä kansanrunoudesta" (Rintama 18/1934):

[...] yleensä kaiken, rakennustyötämme ja uutta neuvostokulttuuria avustavan folklorin kehitystä on kaikin puolin edistettävä. Vahingollisen, luokkavieraan ruikutuksen tilalle on saatava terveen folklorin tuotteita. Neuvostokirjailijoiden on ryhdyttävä luomaan proletaarisia lyyrillisiä runoja ja lauluja sekä kaikkien eri juhlatilaisuuksien ohjelmistoon tarvittavia 'pieniä muotoja' [...] Siis uutteraan työhön folklorin ilmentämiseksi, edistämiseksi ja tunnetuksitekemiseksi!

Kalevalan juhlavuonna 1935 myös professori Yrjö Sirola ohjaa, kenties tietämättään, suuntaviivoja myöhemmin kehittyvälle neuvostokalevalaiselle runoudelle loiventamalla käsitteellistä eroa "reliikin" ja "nykyperinteen" välillä (Sirola 1935, 123):

Jos Kalevalan runojen aikaisen kansan elämä, työ ja taistelu innoittivat runoilijoita luomaan niin kauniita teoksia, että me yhä voimme niistä nauttia, niin kuinka paljon valtavampiin tuotteisiin täytyykään kirjailijoitamme innoittaa sosialismin rakentaminen, vapautuva työ, taistelu kommunismin puolesta [...] [P]roletaarisessa vallankumouksessa voittaa todellisuus sadun. Me elämme siinä todellisuudessa. Ja sen runouden täytyy olla sen suuren sisällön arvoinen.

Vuoden 1935 jälkeen Neuvostoliitossa alkoi uutta sosialistista todellisuutta kuvaavan kansanperinteen keruuohjelma (Miller 1990, 6-7), ja sosialistista todellisuutta kuvaavan nykyperinteen keruu kiihtyi vuoden 1937 jälkeen etenkin musiikin osalta mutta muutenkin (Zemtsovsky ja Kunanbaeva 1997, 7). Esimerkiksi Leningradissa järjestettiin vuonna 1937 Karjalan taiteen päivät, joiden yhteydessä esiintyi kolhoosilaisten kansanmusiikkikuoroja. Ne esiteltiin spontaanisti ja työläisten aloitteesta syntyneinä, mutta samankaltaisia perustettiin miltei kaikkialla Neuvostoliitossa yhtaikaa, saman byrokraattisen kaavan mukaan (Mikkonen ja Suutari 2006, 160). Neuvostoliiton keskusjohto siis nosti määritelmällisesti instituutioiden ulkopuolista kansankulttuuria esiin luomalla (hiukan ristiriitaisesti) esiintuomiselle tarpeellisia institutionaalisia puitteita.

1930-luvun jälkipuolella Neuvostoliitossa alettiin myös enemmän tai vähemmän järjestelmällisesti valistaa kansantaiteilijoita. Heidän koteihinsa asennettiin radioita, heille tilattiin sanomalehtiä ja heitä kuljetettiin vierailemaan suurkaupunkeihin tutustumaan sosialismin saavutuksiin (Olson 2004, 41; Miller 1990, 13-14; Oinas 1973, 52). Vuodesta 1938 alkaen runonlaulajia otettiin Neuvostokirjailijain liiton jäseniksi (Olson 2004, 52-57), mistä seurasi heille merkittäviä etuja - ja minkä myötä heidät luettiin entistä vahvemmin samojen velvollisuuksien alaisiksi kuin kirjailijat yleisemminkin. Yleisen kirjallisuuden tehtäviin liittyvän keskustelun tuona aikana voi katsoa koskeneen paljolti myös runonlaulajilta julkaistavia tekstejä. Kirjailijaliiton tapaisten kulttuurijärjestöjen kautta puolueen johto pyrki ohjaamaan luovia kykyjä toimimaan koko kansan ja sosialismin rakentamisen hyväksi. Liitto tarjosi huomattavia etuja jäsenilleen, kuten hyvän eläkkeen, ja liiton jäsenyyden takaamilla 
kirjoituspalkkioilla oli mahdollista tulla toimeen (Zezina 1994, 650). On hyvä huomata, että liiton tarjoamat etuisuudet riippuivat työn ideologisesta tasosta vuodesta 1950 alkaen (Tolz 2002, 97-99). Voidaan olettaa, että työn ideologinen taso oli myös jäseneksi hyväksymisen kriteerinä, mikä saattoi vaikuttaa jäsenyyttä hamuavien kirjoittajien työhön.

Esimerkkeinä runonlaulajien ohjaamisesta mainittakoon, kuinka Nikolai Leontjev kasvatti bylinalaulaja Maremjana Golubkovaa ideologisesti kertomalla Neuvostoliiton ihmeistä, joita tämä sitten sovitti novinoiksi (Ziolkowski 2013, 87-89) ja Viktorin Popov kertoi toimittaneensa bylinalaulaja Marfa Kriukovalta vuosien kuluessa tallentamiaan bylinoita korjaamalla niitä rakenteellisesti ja tyylillisesti julkaisemista varten (Olson 2004, 42). Popov auttoi kertomansa mukaan laulajaa sijoittamaan tietyt tapahtumat oikeisiin historiallisiin yhteyksiinsä, poisti runoista osia jotka eivät liittyneet sen kokonaisteemaan, poisti tarpeetonta toistoa ja kuvailuja, ja oikaisi teksteissä Vienanmeren alueen murteen outouksia (Sokolov 1966, 677; Oinas 1973, 52). Runonlaulajan ideologinen kasvattaminen ja opastaminen merkitsi tässä yhteydessä myös varsin reipasta toimituksellista puuttumista hänen runojensa sisältöihin.

Folkloren ohjaaminen oli siis säilyneiden tietojen valossa Neuvostoliitossa keskusjohtoista (ks. Miller 1990, 12; Herzog 2010, 119-120; Baldano ja Varnaskiy 2016). Se käsitti enimmäkseen perinteentaitajien ideologianmukaista valistamista sosialismin myönteisistä puolista, rohkaisemista tämän ideologian mukaisten teosten sepittämiseksi, ja myös heidän teostensa toimittamista ja muokkaamista julkaisun alla. Ohjaus oli siis varsin samankaltaista sensuuria kuin mitä suunnattiin kirjailijoita ja muita taiteilijoita kohtaan, joskaan ei samalla tavoin eikä yhtä lailla valikoiden (ks. Kurki 2018, 38-40). Neuvosto-Karjalassa ohjaus tapahtui joka tapauksessa tiiviissä yhteydessä kirjailijajärjestöön.

\section{Runonlaulajien ohjaaminen Neuvosto-Karjalassa}

Kansanperinteen tallennus ja perinteen esittäjien ohjaus kuului Neuvosto-Karjalassa paikallisen kirjailijaliiton tehtäviin. Tämä liittyi asiaan liittyviin dokumentteihin perehtyneen Mikko Ylikankaan mukaan ainakin osin Petroskoin ja Leningradin kirjailijaliittojen väliseen kilpailuun ja erimielisyyksiin työnjaosta liittojen kesken. Leningradilaiset kaavailivat Karjalan liitosta kansanperinneliittoa ja rohkaisivat Ylikankaan mukaan sen kehittymistä tähän suuntaan (Ylikangas 2004, 439). Kansanrunous oli todettu tärkeäksi malliksi kirjallisuudelle, mutta ongelma oli, että runonlaulajat lauloivat vanhakantaista runoutta, joka ei ollut ideologisesti oikeaoppista. Karjalan neuvostokirjailijoiden liiton vastanimitetty puheenjohtaja Pavel Sokolov (tiettävästi ei sukua Juri Sokoloville) esitti vuonna 1938 kommunistipuolueen Karjalan aluekomitealle, että runonlaulajien ideologinen kasvattaminen aloitettaisiin määrätietoisesti muutaman valikoidun runonlaulajan kohdalla. Sokolov vetosi hyviin kokemuksiin Dagestanissa (Suleiman Stalski) ja Kazakstanissa (Džambul Džabajev) (Ylikangas 2004, 430). Petroskoissa järjestettiin 25.-30.5.1939 yleiskarjalainen kansantaiteen mestareiden konferenssi, jonka jälkeen karjalaisen kirjailijaliiton yleiskokouksessa 25.6.1939 todettiin, että "koska Karjalan liitto oli selvästi kirjailijoiden ja runonlaulajien liitto, päätettiin sen yhteyteen perustaa kansantaiteen jaosto. Sen tehtävä oli kouluttaa runonlaulajia Sokolovin aikaisemmin kaavailemalla tavalla ja toimittaa heidän teoksiaan julkaistaviksi." (Ylikangas 2004, 443.)

Runonlaulajien ohjaamisen toteutus oli paikallisen puoluejohdon valvonnassa. Karjalan kommunistipuolueen sihteeri Josef Sykiäinen nosti asian esiin puoluejohdon nimissä kirjoituksessaan "Kirjallisuusliikkeen tehtävistä Karjalais-suomalaisessa SNT:ssä": 
On välttämätöntä laajentaa kertojain maailmankatsomusta, kasvattaa heitä, että he voisivat antaa huomattavampia tuotteita nykyajan aiheista, ja pääasia, mikä kirjailijain liiton täytyy tehdä, on väsymättä tehdä työtä heidän aatteellisen ja taiteellisen tasonsa kohottamiseksi [...] Kansantarujen kertojain edelleen kehittäminen vaatii sitä, että me kirjoittaisimme muistiin ja julkaisisimme vain täyspainoiset, jättäen syrjään huonot, samanaikaisesti osoittaen kertojille heidän virheensä. (Sykiäinen 1940, 16.)

Kirjailijaliitto ottikin ohjeesta vaarin. Karjalan kirjailijaliiton edustajakokouksen raportissa alkuvuodelta 1941 runonlaulajien kasvattaminen ja ideologisesti oikeaoppisen folkloren juurruttaminen kansan käyttöön luetaan sekä kirjailijaliiton että vuonna 1937 perustetun Karjalan kulttuurin tieteellisen tutkimusinstituutin tutkijoiden tehtäväksi:

\begin{abstract}
Neuvostokansanrunouden tulee olla ei ainoastaan kansanrunouden harrastajia, vaan koko kansaa varten. Täytyy tehdä niin, että uusia tuotteita ei ainoastaan painettaisi aikakausjulkaisuissa, vaan että ne kulkisivat suusta suuhun [...] Kulttuurin Tieteellisen Tutkimusinstituutin ja Neuvostokirjailijain liiton on johdettava kansanrunouden kehitystä, kasvatettava runonlaulajia, autettava heitä luodessaan neuvostoaiheisia tuotteita. Kokemus osoittaa, että johdonmukaisella avulla runonlaulajat voivat muuttua omalaatuisikseen runoilijoiksi [...] Järkiperäisellä avulla, runonlaulajien, satuseppojen ja kirjailijain yhteisellä työllä me voimme saavuttaa suuria saavutuksia, jotka saattavat Karjalais-Suomalaisen kansantaiteen kukoistamaan. (Punalippu 1/1941, 111.)
\end{abstract}

Samana keväänä järjestetyn runonlaulajien konferenssin jälkeen Punalipun 5/1941 pääkirjoituksessa todetaan, että eläminen sosialistisessa yhteiskunnassa heijastuu myös kalevalamittaiseen traditioon:

On mielenkiintoista panna merkille, että runonlaulajat aivan oma-aloitteisesti sepittävät Kalevalan mitalla uusia lauluja uudesta elämästä [...] Ei ole olemassa niin kaukaista korpikylää tai metsämökkiä, jonne ei kantautuisi uuden elämämme, sosialistisen rakennustyön valtava sykähtely. Ja tämän sykähtelyn vaikutuksesta runonlaulaja tarttuu kanteleeseensa, hänen mielessään ailahtelee sellaista, joka on saatava sanoiksi, sommiteltava säkeiksi. (s. 2)

Onkin aivan mahdollista ja jopa todennäköistä, että muuttunut elinympäristö vaikutti perinteen muotoutumiseen (Alin 1988, 52-54). Samaan aikaan neuvostokarjalaisessa lehdistössä kuitenkin todetaan, että tällä tavoin syntyvien runojen sisältöjen vastaavuus sosialistisen todellisuuden kanssa vaatii poliittista ohjausta:

Mutta useinkin laulajavanhukset, kykenemättä tarkasti seuraamaan aikamme rientoja, eivät saa lauluihinsa aikaamme vastaavaa sisältöä. Tämän vuoksi Kulttuuritutkimusinstituutin ei ole rajoituttava vain laulujen keräämiseen, niiden tutkimiseen ja julkaisemiseen, vaan sen on myöskin autettava runonlaulajia uusien laulujen luomisessa kartuttamalla heidän tietojaan. (s. 2)

Neuvosto-Karjalassa runonlaulajien ohjaamisen tarve oli siis sisäistetty varsin luontevasti, ja ennen toista maailmansotaa siitä puhuttiin julkisesti. Sodan jälkeen uusaiheisia runoja pidettiin jo vakiintuneena kansankulttuurin muotona, kuten on luettavissa folkloristi Viktor Jevsejevin tekstissä:

Venäjän tsarismin hirmuvallan aikoinakaan Karjalan raatajarahvas ei unohtanut ylvästä kansanrunouttaan. Sitä suuremmalla syyllä Neuvostoliiton oloissa kansamme urotyöt velvoittavat kehittämään Kalevalan laulua edelleen [...] Kansanrunous on muinaisuuden ja nykyisyyden, kansan elämän ja kansan psykologian elävä kuvastin [...] [V]aikka käyneekin niin, että suullisena tuotteena varhaisruno häviää, niin kuitenkin vanha kansanrunous uudistuneine sisältöineen ylistää uutta sosialistista yhteiskuntaa ja kommunismin rakentamista Neuvostoliitossa. (Jevsejev 1947, 97-98.) 
Vaikka runonlaulajien poliittisesta ohjauksesta käytiin lehdissä avointa keskustelua, itse runojen neuvostojärjestelmää ylistävä ja kuulijoita agitoiva sisältö esitetään kuvauksissa kansan syvien rivien spontaaniksi itseilmaisuksi. Tämä ilmenee esimerkiksi kuvausten ihmettelevässä asenteessa tai prosessin lopputuloksiin ja runojen sepittäjiin keskittymisessä. Esimerkiksi Josef Sykiäinen, joka kirjoitti runonlaulajien kasvattamisesta, mainitsee samassa tekstissä, että "suurin osa heistä on ottanut nykypäivien aihepiirin lauluihinsa ja taruihinsa" (Sykiäinen 1940, 8), ja Eini Gran $(1947,174)$ kirjoittaa, kuinka "[n]ämä runot osoittavat, miten syvällä Karjalan kansan sydämessä elää kunnioitus ja luottamus kommunistista puoluetta, neuvostovaltaa ja johtajaamme toveri Stalinia kohtaa," joskin vuonna 1954 hän kirjoittaa, että kirjailijaliitto on lyönyt laimin runonlaulajien ohjaamista uusien aiheiden pariin (Gran 1954, 127-128). Huomautuksen hän koki tarpeelliseksi kenties Stalinin kuoleman vuoksi.

Neuvostokalevalaisen runouden syntymistä ja sisältöjä ei siis jätetty Neuvosto-Karjalassa sattuman varaan, vaan sen kehittyminen tapahtui keskusjohtoisesti kirjallisuusliiton ja kansanperinteentutkijoiden ohjauksessa samanaikaisesti, kun vastaavia prosesseja oli käynnissä myös muualla Neuvostoliitossa. Runonlaulajien ohjaamisen tärkeyden ohella, ja osin samaan hengenvetoon, korostettiin runojen spontaania luonnetta kansan syvien tuntojen ilmaisijana - ikään kuin poliittisen ohjauksen tuloksena syntyneet runot olisivat spontaania ilmaisua. Ristiriita oli ilmeinen ja vielä ennen toista maailmansotaa peittelemätön.

\section{Uusaiheisesta perinteestä neuvostokalevalaiseen runouteen}

Julkaistujen tekstien ohella myös Karjalan tiedekeskuksen arkistossa on säilynyt runonlaulajilta tallennettuja tai heidän kirjoittamiaan runoja. Vaikkei niitä ole julkaistu lehdissä tai kokoelmissa, niitä on usein esitetty esimerkiksi paikallisissa juhlatilaisuuksissa. On syytä huomata, että arkistoista löytyvä, julkaisematonkin aineisto on todennäköisesti ainakin jossakin määrin arkistointiprosessin eri toimijoiden - kerääjistä lähtien - harjoittaman sensuurin rajaamaa eikä anna koko kuvaa folkloren tilasta neuvostoaikana: esimerkiksi neuvostokriittisiä vitsejä, jotka olivat yleensä hyvin suosittuja (ks. esim. Thurston 1991), ei arkistosta löydy. Toisaalta toista maailmansotaa edeltävissä arkistoaineistoissa on luultavasti merkittäviä puutteita Suomen armeijan jatkosodan aikaisen Itä-Karjalan miehityksen jäljiltä. Tällöin suomalaisten kaappaamat arkistoaineistot joutuivat sekasortoiseen tilaan, sillä sen lisäksi että sitä tuhoutui miehitysaikana tulipalossa (Kruhse ja Uitto 2008, 99-102), suomalaiset myös kuljettivat jäljellejääneestä aineistosta osan Suomeen eri arkistoihin ja joutuivat sodan jälkeen kokoamaan aineistoa uudelleen yhteen palauttaessaan sen takaisin. Sodan kaaoksesta on SKS:n perinnearkiston aineistossa kuvaava alikersantti Väinö Tuomaalan maininta, jonka mukaan hän onnistui sattumalta pelastamaan Petroskoissa syksyllä 1941 kansanperinnemuistiinpanoja, jotka oli miehityksen yhteydessä "paiskattu rikkaläjään jollakin takapihalla" (SKS KRA 290).

Uusaiheiset runot poikkesivat aiemmin julkaistuista perinteen muotoa hyödyntävistä taiderunoista etenkin "autenttisuuttaan" eli sillä, että ne liittyivät perinnekulttuuriin kiinteämmin olemalla korostetusti perinnekulttuurin edustajien sepittämiä. Esa Alinin (1988, 52) mukaan yhteiskunnallinen sisältö neuvostoaiheisissa runoissa mahtuu joissakin tapauksissa jopa perinteisen runouden "tilapäisen ja tilannekohtaisen" muuntelun piiriin ja kirjalliseen muotoon pukeminen on vain jähmettänyt tämän varioinnin. Näkemys ei kuitenkaan oikein suhteudu uusaiheisen runouden kokonaiskuvaan - kyse on kuitenkin laajasta ilmiöstä, jota ohjasivat lisäksi keskushallinnon poliittiset intressit. Sen sijaan neuvostoliittolaisessa 
keskustelussa uusaiheisten runojen yhteiskunnallisten sisältöjen autenttisuutta pyrittiin korostamaan. Kalevalamittaiset runot saivat lopulta uusaiheisesta aineistosta eniten huomiota, mutta etenkin varhaiset julkaisut edustavat myös muita muotoja kuten tšastuškoja eli pajoja ja itkuvirsiä.

Karjalankielisten sepitettyjen kansanrunojen julkaisu vuonna 1937 liittyy ainakin jossakin määrin kielipoliittiseen päätökseen kieltää tyystin suomenkielinen julkaiseminen suomalaiseen nationalismiin viittaavana ja sellaisena Neuvostoliiton yhtenäisyydelle vaarallisena, mihin liittyi paikallisen etnisen kulttuurin karjalaisuuden korostaminen suomalaisuuteen viittaamisen sijaan. Suomenkielisen julkaisemisen sijaan siirryttiin esimerkiksi varta vasten kehitetyn karjalan kirjakielen käyttöön, jota julkaistiin kyrillisin kirjaimin. (Ks. Ahola 2020, 5.) I. Fokinin (1937) runo "Кюля эннен и нӱгӧй" ('Kylä ennen ja nykyään') hakee muotoa tšastuškoilta, ja se rakentuu myöhemmissä perinteestä kumpuavissa runoissa tavallisen aiheen varaan elämän huonommuudesta ennen vallankumousta verrattuna sen jälkeiseen aikaan (mikä oli myös keskusjohdon ohjeistama aihe, ks. Miller 1990, 12). Kaksiosaisessa runossa esitellään maaseutukylän oloja ensin tsaarin vallan alla, sitten vallankumouksen jälkeen, kuten tässä otteessa:

\author{
Колхозан суурий пелдолой \\ Тракторойл вайн кӱннетӓх \\ Эндижет пууадру-рашкат \\ Музейлойс - муйстона вирутах \\ 'Kolhoosin suuria peltoja \\ Traktoreilla vain kynnetään \\ Entiset puuaura-raiskat \\ Museoissa muistona viruvat'
}

(Fokin 1937)

Punainen Karjala julkaisi viikkoa myöhemmin myös yksittäisen kolhoosilaisen, F. Kondratjevin (1937) kertovan todistuksen tästä aiheesta. Runon näkökulma on kylän asukkaan, joka tarkastelee oloja hyvin konkreettisesti.

Ensimmäiset julkaistut karjalankieliset uusaiheiset itkuvirret liittyivät Leninin kuolemaan. Leninin kuoleman 15-vuotismuistovuonna Karelija-lehdessä julkaistiin M. F. Pavkovan (1939) itku "Вирзы Ленинах нӓх" ('virsi Leninille') ja myös numerossa 1-2/1940 julkaistiin Leninille omistettuja karjalankielisiä itkuvirsiä. Punalippu 1/1941 julkaisi Leninille omistetun itkuvirren suomalaisessa kontekstissa, suomalaisittain normalisoituna ja latinalaisin aakkosin (Hotejeva 1941). Näitä itkuvirsiä on tallennettu arkistoon Maura Hotejevalta kolme kappaletta vuodelta 1937 (KarTK F. 1 op. 2 kok. 20 säil.yks. 66-68 I. 352-359). (Ks. myös Stepanova 2014, 182-186.) Myös ensimmäiset Neuvostoliitossa julkaistut sosialistiseen todellisuuteen ja maailmankuvaan viittaavat kansanperinnetuotteet olivat Leninin kuoleman (1924) kirvoittamia tekstejä, joita julkaistiin Neuvostoliitossa 1920-luvulla (Panchenko 2005, 20-24). Neuvostoliiton ensimmäiset suuret johtajat kohosivat myös Neuvosto-Karjalassa satujen hahmoiksi. Vuonna 1941, ensimmäisessä varsinaisessa uusaiheisten karjalaisten perinnetuotteiden luonnehdinnassa Viktor Jevsejev $(1941,117)$ kirjoittaa, kuinka "mielenkiintoista" on, että sadunkertojat kuvaavat uusissa saduissaan "Leniniä ja Stalinia kansallisten Kalevalan sankareiden johtajina." Suurmieskultti olikin pysyvä osa uusaiheista perinnettä. 
Keväällä 1937 Punainen Karjala 11.3.1937 julkaisi Maria Remsun (1937) sepittämän tšastuškan tapaisen runon "Matkalaulu", joka kuvasi hänen matkaansa Petroskoihin kutsuttuna perinteentaitajana yhdessä Maura Hotejevan kanssa (ks. myös Mikkonen ja Suutari 2006, 164-165). Runossa ei ole varsinaista poliittista sisältöä, mutta perinteen edustajan vaatimaton näkökulma suhteessa sosialismin ihmeisiin on näkyvissä. Syksyllä 1937 julkaistiin Leningradskaja Pravdassa kaksi Anastasija Nikiforovan perinteistä muotoa edustavan runon tekstiä, jotka käsittelevät sisällissodan ajan taistelua suomalaisia vastaan ja vakoilijan kiinnijäämistä Karjalan metsissä (Jevsejev 1950, 503, 505). Ensimmäinen näistä päättyy suomalaisupseerin nöyryytykseen neuvostojoukkojen yllättäessä hänet:

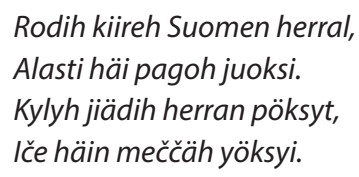

1930-luvun puolelta on säilynyt tallennettuja uusaiheisia runoja ainakin Anastasija Nikiforovalta, Varvara Prohorovalta, Jefrem Prohorovilta, Anna Malikinalta, Maura Hotejevalta ja Jouki Hämäläiseltä. Näistä kertovista runoista monet tapailevat kalevalamittaa, vaikka edustavat uudempaa laulukulttuuria ja sen mukaisia konventioita - kuten äänitteistä on todettavissa.

Talvisodan jälkeen ja Karjalais-Suomalaisen SNT:n perustamisen jälkeen Punalippu 1/1941 julkaisi Karjalais-suomalaisen SNT:n neuvostokirjailijoiden ensimmäisestä edustajakokouksesta raportin, jossa todetaan, että "[u]uden sankarin tyyppi kansanrunoudessa on kiinteästi todellisuudesta. Parhaimmat laulunsa, tarunsa, legendansa, bylininsä ja satunsa omistavat runonlaulajamme johtajilleen Leninille ja Stalinille, heidän työtovereilleen - kansamme sankareille." (s. 110.) Raportin mukaan kaikki perinteen esittäjät "laulavat sosialistisesta synnyinmaastaan, kansojen johtajista, iloisesta ja onnellisesta elämästä" (s. 110). Samana keväänä 1941 järjestettiin runonlaulajien konferenssi, jossa esitettiin, tuotettiin ja kirjattiin perinteisen runon ohella myös uusaiheista runoutta. Konferenssin tuloksia julkaistiin Punalipun numerossa 5/1941, jossa on perinteisten runojen lisäksi Kiril Haurisen sepittämät "Vanha aika" ja "Runo Kemin tiestä", Maria Mihejevan "Runo Stalinista" ja Tatjana Perttusen runomuotoinen kuvaus itsestään laulajana.

Toisen maailmansodan jälkeen uusaiheisista runoista julkaistiin enää lähinnä vain kalevalamittaisia runoja, jotka sisältöjensä puolesta keskittyvät hyvin paljon kuvaamaan neuvostopropagandan mukaisia aiheita. Uusaiheista runoutta voi tässä vaiheessa kuvata "neuvostokalevalaiseksi runoudeksi". Runonlaulajlta talletettiin myös muunmuotoisia tekstejä, mutta niitä ei juurikaan julkaistu. Kalevalamittaisen runouden suosiminen julkaisuissa liittyi epäilemättä ennen muuta sen assosioimisesta Kalevalaan, joka oli kansainvälisesti arvostettu ja tunnettu eepos. Neuvosto-Karjalassa propagoitiin Kalevalan karjalaisuutta, ja elävä kalevalamittainen perinne oli yksi argumentti sen puolesta (Ahola 2020). Kalevala edusti samaan aikaan sekä kunnioitettua monisukupolvista traditiota että vanhakantaisia, 
taantumuksellisia käsityksiä. Oli propagandistisesti tehokasta värvätä Kalevalaan assosioitu runonlaulu uuden ideologian palvelukseen - mihin siis runonlaulajien ohjaamisella pyrittiin. Lisäksi kalevalamittaisella epiikalla on luonnostaan kertova muoto, jolla voi ilmaista runsaita sisältöjä. Se toimii myös suhteellisen hyvin painetussakin muodossa ja on suurelle yleisölle suhteellisen helposti ymmärrettävää.

Jatkosodan päätyttyä mutta Suuren isänmaallisen sodan yhä jatkuessa Saksaa vastaan Totuus julkaisi Kalevalanpäivänä 28.2.1945 Kalevalaa käsitteleviä artikkeleita, ja samassa yhteydessä julkaistiin myös kaksi kalevalamittaista runoa, Maria Mihejevan "Runo Stalinista" (Mihejeva 1941) ja Neuvostoliiton menestystä taloudessa ja sodassa metaforisesti kuvaava E. I. Mininin runo "Uusi sampo". Erityisesti jälkimmäinen uhkui sodan aiheuttamaa katkeruutta mutta myös uskoa voittoon:

\author{
Silloi nemtsat Gitleran kel \\ meijen pääle napadittih. \\ Tallai naisii nemtsan tanku, \\ tappoi lapsii shäälimätty. \\ Nousi rahvas nemtsoi vastah, \\ kaiken vihamiehil kosti.
'Silloin saksalaiset Hitlerin kanssa meidän kimppuumme kävivät Tallasi naisia saksalaisen tankki, tappoi lapsia säälimättä. Nousi kansa saksalaisia vastaan, kaiken vihamiehille kosti.'

(Minin 1945)

Punalipussa 3/1947 julkaistiin useita sota-aiheisia runoja, jotka noudattelevat kansanrunouden muotoa: Anastasija Nikiforovan (1947) runo "Sovetskoi muan suuri seppy", jossa IImarinen takoo traktorin ja tykkejä Stalingradin taisteluita varten, Marian Mihejevan (1947a, b) runot "Jopa Saksakin surevi...", joka kuvaa voitonriemuisesti Suomen ja Saksan sotavoimien kokemaa tappiota, ja runo "Pian siirtyy synkkä aika", joka valaa rohkeutta jälleenrakennustyöhön. Lisäksi numerossa on P. Rjabinin-Andrejevin (1947) suomennettu "Bylina marsalkka Rokossovskista", joka on venäläisen bylinarunouden muotoon sepitetty kuvaus Kiovan tienoilla käydyistä taisteluista. Arkistossa löytyy lisäksi jatkosotaan liittyen esimerkiksi Jouki Hämäläisen runot, jotka kertovat pakolaisuudesta suomalaismiehityksen alta (KarTK F. 1 op. 2 kok. 23 säil.yks. 60a I. 217-218) ja ilosta sodan päättymisen vuoksi (KarTK F. 1 op. 2 kok. 23 säil.yks. 60 I. 166).

Sota-aiheiset runot jäivät tämän jälkeen julkaisuista syrjään, ja kansanrunouden pohjalta kumpuavat runot keskittyivät 1950-luvulle tultaessa sosialistisen järjestelmän ylistämiseen. Sodan aikana ja heti sen jälkeen hyökkääjävaltion kieltä, suomea, vältettiin runoissa, mikä saattoi johtua propagandistisista syistä mutta ehkä myös karjalaisten emotionaalisesta suhtautumisesta sotatapahtumiin. Runojen kieleksi vaihtui kuitenkin suhteellisen pian taas suomi, mikä johtui varmastikin ennen muuta niiden julkaisualustojen kielestä. Kertovaa runoutta harjoittavien runonlaulajien käyttämä karjalan murre ja varsinkin kalevalakieli oli muutenkin Vienan Karjalassa etenkin Suomen rajan läheisyydessä varsin lähellä suomea (ks. Torikka 2003, 4). 
Hallitsevia aiheita ovat erityisesti kolhoosien maatalouden tehokkuus, uusi teknologia kuten traktorit, sähkösahat ja sähkövalo, sekä poliittisen johdon kyvykkyys. Sosialistisen yhteiskunnan vaurauden ja elämän helppouden liioitteleva kuvaus oli melkoisessa ristiriidassa sodanjälkeisen puutteen kanssa, mutta se oli myös valtiojohtoisissa medioissa tavallinen puhumisen tapa (vrt. Annus 2018, 111-113). Mielenkiintoista kyllä suurin osa sekä julkaistuista että arkistoon tallennetuista runoista on tässä vaiheessa suomenkielisiä, vaikka suomi oli etenkin 1930-luvun kansallisuusvainojen jälkeen häviävän pienen kansanosan vähemmistökieli, tosin Neuvosto-Karjalassa toinen virallinen kieli. Suurin osa Karjalan tiedekeskuksen arkistoon tallennetuista runoista on 1940-luvun jälkipuolelta ja 1950-luvun alkupuolelta, eikä Stalinin kuolinvuoden 1953 jälkeen ole arkistoon tallennettu käytännössä lainkaan uusia sepitelmiä. Viktor Jevsejev julkaisi uusaiheista runoutta venäjänkielisinä käännöksinä (Jevsejev 1940) ja alkukielisinä käännöksineen (1950). Tunnettujen runonlaulajien, etupäässä uhtualaisten Maria Mihejevan, Jouki Hämäläisen ja Tatjana Perttusen runoja julkaistiin Punalipussa lähes vuosittain. Tekstilajina neuvostokalevalainen runous alkoi olla kehittynyt pisteeseen, jossa runojen ilmaisuissa on paljon yhdenmukaisuutta, rakenteet ovat vakiintuneita ja mitan merkitsevät piirteet suhteellisen säännöllisiä.

Kalevalamitan käyttö - ilmeisin ja tiukin kriteeri perinteenmukaisuudelle - oli 1940-luvun puolivälin jälkeen systemaattista, joskin erityisesti perinteelle vieraan terminologian kohdalla runoissa on usein erityyppisiä lapsuksia, jotka vaihtelevat painollisen tavun väärästä pituudesta aina tavujen määrään säkeessä. Ideologiapohjaisten metaforien ja uuden terminologian sovittamisessa kalevalamittaan on kuitenkin myös merkittäviä onnistumisia, kuten Jouki Hämäläisen runon hyvämuotoinen säe, joka käsittää vain yhden sanan:

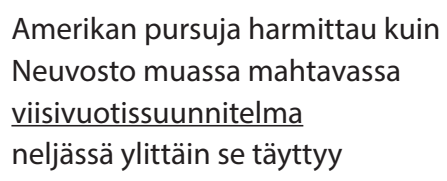

(KarTK F. 1 op. 2 kok. 23 säil.yks. 55 I. 155)

Kalevalakielelle keskeiset alkusointuisuus ja parallelismi ovat runoissa vahvassa käytössä, ja ne ulottuvat monesti runollisina keinoina myös kalevalamitasta poikkeaviin teksteihin. Perinteenmukaisuuden tavoitteleminen antaa usein liioittelevine kuvauksineen korostetun kouluttamattoman ja takapajuisen vaikutelman, mikä ilmeisesti kuului runonlaulajien omaksumaan habitukseen kansanomaisina perinne-ekspertteinä. Esimerkiksi Maria Mihejevan myöhäiseen tuotantoon kuuluvassa runossa "Laulan lokakuusta" kuvataan uutista Sputnik-satelliitin laukaisemisesta seuraavasti:

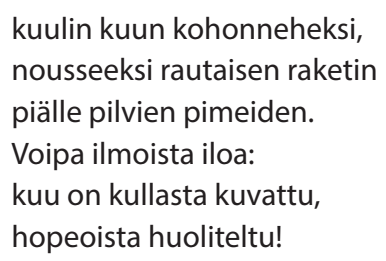

(Mihejeva 1964)

Perinteessä vakiintuneiden runosäkeiden kielikuvat, jotka liittyivät runokulttuurissa tiettyihin referentteihin tai aiheisiin, saivat usein uusaiheisissa runoissa uuden, eri kautta 
ymmärrettävän merkityksen runon sisällön myötä. Yllä olevassa runoesimerkissä olevat elementit "kullasta kuvattu / hopeoista huoliteltu" liittyvät perinteessä lähinnä myyttiin, jossa Ilmarinen takoo itselleen kullasta vaimon. Toisaalla Maria Mihejeva käyttää epiteettiä "takoja ijänikuinen" perinteenmukaisesti viittaamaan seppä Ilmariseen, mutta samassa runossa hiukan myöhemmin monikossa kirveitä käytteleviin metsureihin, ja tällä tavoin rakentaa jatkuvuutta karjalaisten myyttisen menneisyyden ja sosialistisen nykyisyyden välillä (Mihejeva 1949). Säepari "Eikä kolkkais kallijoihe / Eikä kimmastuis kivihin", joka suullisessa perinteessä liittyy tyypillisesti Väinämöisen polvenhaavasta kertovaan verensulkuloitsuun (esim. "Ei kirves kivehen kolka, / Eikä kalka kallivoho"5) viittaa Mihejevan neuvostokalevalaisessa runossa (KarTK F. 1 op. 2 kok. 26 säil.yks. 1 I. 24) tukkipuiden esteettömään kulkuun uiton yhteydessä. Perinteessä vakiintuneet säkeet ja säeryppäät edustavat neuvostokalevalaisissa runoissa perinteellisyyttä, joka uusissa yhteyksissä saa uusia merkityksiä, mutta niiden käyttö voi viitata myös perinteisen runouden esittäjien tapaan tukeutua esityksissään vakiintuneisiin säeyksikköihin.

Neuvostokalevalaisen runouden ja muun uusaiheisen runouden välille on monesti vaikea vetää selkeää rajaa esimerkiksi metrisestä epätasaisuudesta ja kalevalakielelle vieraiden runokeinojen, kuten loppusoinnun, käytöstä johtuen. Vaikka runonlaulajilta julkaistiin selkeästi eniten kalevalamittaisia tekstejä, heiltä löytyy arkistosta myös muodoltaan kalevalamitasta poikkeavia tekstejä vielä toisen maailmansodan jälkeenkin. Etenkin Jouki Hämäläinen, joka oli runojen sepittäjänä hyvin tuottelias, haki ilmaisuunsa ilmeisen määrätietoisesti monipuolisuutta myös perinteisen runouden keinoston ulkopuolelta. Toisaalta Hämäläiseltä on säilynyt myös hänen kirjoittamansa jatkosodan alkua Latvajärvellä kuvaava teksti, joka vaikuttaa heijastavan sitä, kuinka helposti hänen kerrontansa taipui kalevalakieleen. Teksti alkaa dramaattisella proosamuotoisella kuvauksella suomalaisten hyökkäyksestä Vienaan. Osuus on ryyditetty kalevalakielisillä ilmauksilla, kuten kuvauksessa siitä, kuinka asukkaat pyrkivät pakenemaan Vuokkiniemeltä "Kuittijärven kuulun poikki, ei venoista valkamoissa, mikä nyt tuumaksi tulou, tapa keinoksi kerkiäy, tähä tappo vainolainen, rahvas hirviesti valitti." Tämän jälkeen teksti kääntyy kalevalamittaisiksi säkeiksi, jotka kuvaavat, kuinka puna-armeija torjui vihollisen yritykset valloittaa Uhtua:

\author{
Eipä uljas Uhtuamme \\ väistynyt ei vähiänä \\ liikahtan ei linnan salvat \\ linnan lukut ei luiskahtanna.
}

(KarTK F. 1 op. 2 kok. 23 säil.yks. 57 I. 158-161, säkeet 21-24)

Sodan jälkeen Stalin on runoissa keskeisessä roolissa, vähintäänkin kiitosten kohteena lähes runon aiheesta riippumatta, ja hänen ylistyksensä saavuttaa merkittävät mittasuhteet (vrt. Miller 1980, erit. 56-63). Neuvostokalevalaiselle runoudelle annetusta arvostuksesta kertoo, että kun Stalinin kuolema vuonna 1953 järkytti koko neuvostokansaa, Punalipun Stalinin muistolle omistetussa numerossa neuvostokarjalaisten kirjailijoiden ja runoilijoiden muistoteksteistä ensimmäinen oli runonlaulaja Jouki Hämäläisen sepittämä "Stalin elää ikuisesti" (Hämäläinen 1953). Karjalan tiedekeskuksen äänitearkistosta löytyy myös Maria Mihejevan ja Tatjana Perttusen muistorunot Stalinille (KarTK äänit. Kok. 14 / säil.yks. 14; KarTK äänit. Kok. 14 / säil.yks. 1). Tämän jälkeen Stalinin ylistys vaihtuu "puolueen" ylistykseksi, eikä Stalinia 
mainita teksteissä enää. Siinä missä muualla NL:ssa uusaiheisen kansanrunouden merkitys väheni huomattavasti Stalinin kuoleman jälkeen, Karjalassa niiden julkaisemista jatkettiin 1960-luvulle asti. Vuonna 1959 julkaistiin Jaakko Rugojevin toimittama uusaiheisten runojen kokoelma Laulu uudesta sammosta, joka käsittää kolmen tunnetuimman laulajan runoja (joista Stalin on siivottu pois). Vielä vuonna 1963 Tatjana Perttusen kuoleman jälkeen Punalippu 3/1963 julkaisi hänelle Jaakko Rugojevin kirjoittaman muistokirjoituksen ja kaksi Maria Mihejevan sepittämää uusaiheista kalevalamittaista runoa, joista toinen on muistoruno hänen edesmenneelle ystävälleen. Vuonna 1981, kun Jouki Hämäläisen syntymästä oli kulunut sata vuotta, julkaistiin Punalipussa 12/1981 retrospektiivinen kokoelma hänen runojaan.

\section{Neuvostokalevalaisten runojen laulajat}

Erotuksena kalevalamittaa hyödyntävistä taiderunoilijoista neuvostokalevalaisten runojen sepittäjät olivat runokulttuurin jäseninä kasvaneet kalevalamittaiseen runoperinteeseen. Kaikilta heiltä on tallennettu myös perinteistä runoutta. Yleensä sepittäjien runonlaulajaidentiteettiä korostettiin julkisissa teksteissä.

Tunnetuimpien neuvostokalevalaisten runojen sepittäjien Tatjana Perttusen, Maria Mihejevan ja Jouki Hämäläisen tausta on Kalevalan piirissä, Vienan Karjalan tunnetuimmilla runotraditioalueilla. Siinä missä ensimmäisen polven uusaiheisten runojen sepittäjistä Maria Remsu ja Maura Hotejeva syntyivät 1865 ja Kiril Haurinen 1870, he ovat kaikki syntyneet 1880-luvun alkupuolella. Tällöin he ovat vielä kasvaneet aktiivisessa perinneympäristössä. Uusaiheisten runojen sepittäminen sattui ajanjaksolle, jolloin he olivat suhteellisen iäkkäitä, yli 55-vuotiaita, mitä ehkä voi pitää edellytyksenä auktoriteettiasemalle runokulttuurissa. Laulajien suhde Kalevalan kannalta keskeiseen ja Suomessa ylistettyyn Perttusten laulajasukuun nostetaan säännöllisesti esiin heidän esittelyissään: esimerkiksi Tatjana Perttusen kuvataan oppineen lapsena runoja lapsenvahdiltaan Miihkali Perttuselta (Timonen 1984, $12,50-53,71$ ) ja hänen miehensäkin olleen samasta suvusta (Jevsejev 1950, 462; ks. KarTK F. 1 op. 2 kok. 24 säil.yks. 28a I. 113). Myös Jouki Hämäläisen kuvataan käyneen usein lapsena naapurikylässä kuuntelemassa tätä (Timonen 1984, 109). Maria Mihejeva kuvaa isäänsä livana Korkkojevia tärkeänä lähteenä omaksumalleen perinteelle, ja livana puolestaan toimi laukkukauppiaana, jolloin hän Timosen mukaan vieraili usein Latvajärvellä ja Vuokkiniemen keskeisissä runokylissä (Timonen 1984, 82-84). Maria Remsun runonlaulajuus liitetään niin ikään Arhippa Perttusen kotikylään Latvajärveen (Mišin 1989, 140). Uusaiheisen kansanperinteen sepittäjät ja esittäjät olivat perinteen erityistuntijoita, joiden tausta liittyi kiinteästi laajasti tunnustettuihin Kalevalan runoille keskeisiin laulajasukuihin varsinkin heidän julkisuuskuvassaan.

Runonlaulajien elämän kovuus nousee esiin heidän omaelämäkerrallisissa teksteissään, ${ }^{6}$ ja sitä nostetaan esiin myös heidän esittelyidensä yhteydessä toistamiseen. Heidän elämäänsä ennen vallankumousta kuvataan köyhäksi ja riiston ja kulttuurisen itseilmaisun rajoittamisen luonnehtimaksi. Kuvaukset osallistuvat neuvostolehdistön vakiintuneeseen puheenparteen, jossa olojen kuvailtiin muuttuvan kansalle paremmiksi vallankumouksen myötä ja kuinka kansaa edustavat runonlaulajat saavat ansaitsemansa arvostuksen: "Neuvostohallitus antaa suuren arvon kansanrunoudelle. Sen sijaan kun tsaarinvallan aikana monet

6 Runonlaulajien omaelämäkerrallisia tekstejä sekä haastatteluiden pohjalta että heidän itse kirjoittamanaan löytyy arkistosta: esim. KarTK F. 1 op. 2 kok. 15 säil.yks. 1; KarTK F. 1 op. 2 kok. 15 säil.yks. 2; KarTK F. 1 op. 2 kok. 25 säil.yks. 41 I. 109. 
runonlaulajista kuolivat puutteessa ja kurjuudessa [...] esiintyy tavallinen kylän nainen, kuten jyskyjärveläinen Aleksandra Korelskaja Moskovassa Tshaikovskille nimetyssä konserttisalissa tuhatlukuisen kuulijakunnan edessä laulaen karjalais-suomalaisen kansaneepoksen sankareista." (Timonen 1949, 35.) Jopa luku- ja kirjoitustaidottomien runonlaulajien hyväksyminen neuvostokirjailijoiden liittoon, mistä he saivat huomattavia etuja, oli merkillepantava kunnianosoitus heidän panokselleen (ks. Mikkonen ja Suutari 2006, 167; ks. kuva 2).

Toisaalta kuvaukset samalla rakensivat runonlaulajista kuvaa sankarillisina kovia kokeneen proletariaatin edustajina, mikä lisäsi heidän tekstiensä painoarvoa. N. Vinogradov (1935) korostaa jo Kalevalan runojen taustalla olleiden runonlaulajien köyhyyttä ja nostaa Miihkali Perttusen tästä kuvaavaksi esimerkiksi, ja uusaiheisten runojen laulajista esimerkiksi Tatjana Perttusen kovan elämän annetaan ymmärtää olleen pohja hänen runoilijalahjoilleen (Kronhaus 1949). Jaakko Rugojev $(1958,114)$ tuo erityisen vahvasti esiin kovan työn jalostavan vaikutuksen uusaiheisten runojen sepittäjille: "Lujassa ovat heidän alkujuurensa olleet eikä rasittavinkaan työ ole voinut tappaa heissä sisäistä kauneutta eikä himmentää heidän valoisaa tulevaisuudentoivoaan. Työ ja aherrus ovat heitä jalostaneet." Runonlaulajien elämän ja olojen vaikeus toistuu myös lukuisissa neuvostokalevalaisissa runoissa. Runonlaulajien kohdalla mainitaan huomattavan usein, kuinka he ovat ottaneet kiitollisina vastaan sosialismin mukanaan tuoneita uudistuksia ja kuinka he esimerkiksi ovat olleet "ensimmäisinä" liittymässä perustettuihin kolhooseihin (esim. Jevsejev 1950, 463; Totuus 23.2.1949). Vaikka lojaalius sosialistiselle järjestelmälle kuuluu aikakaudelle ominaisesti esiin nostettujen henkilöiden stereotyyppiseen luonnehdintaan, narratiivi kovia kokeneista proletariaatin edustajista, jotka ovat kiitollisia vallankumoukselle, on olennainen osa runonlaulajien henkilökuvaa.

Uusaiheisen runouden esittämistä ja luomista on kuvattu lähteissä joissakin paikoin. Tatjana Perttunen oli lukutaidoton, mutta hän kuvaa Palaka Kuikalle 8.8.1949, kuinka sepittää runoja muun muassa "kun sielä meččäkämpällä ukon kera soutelemma kalalla, niin ainahan sitä yhtä ja toista tulou päähä". Hän kertoo esimerkiksi sepittäneensä runon Uudesta sammosta

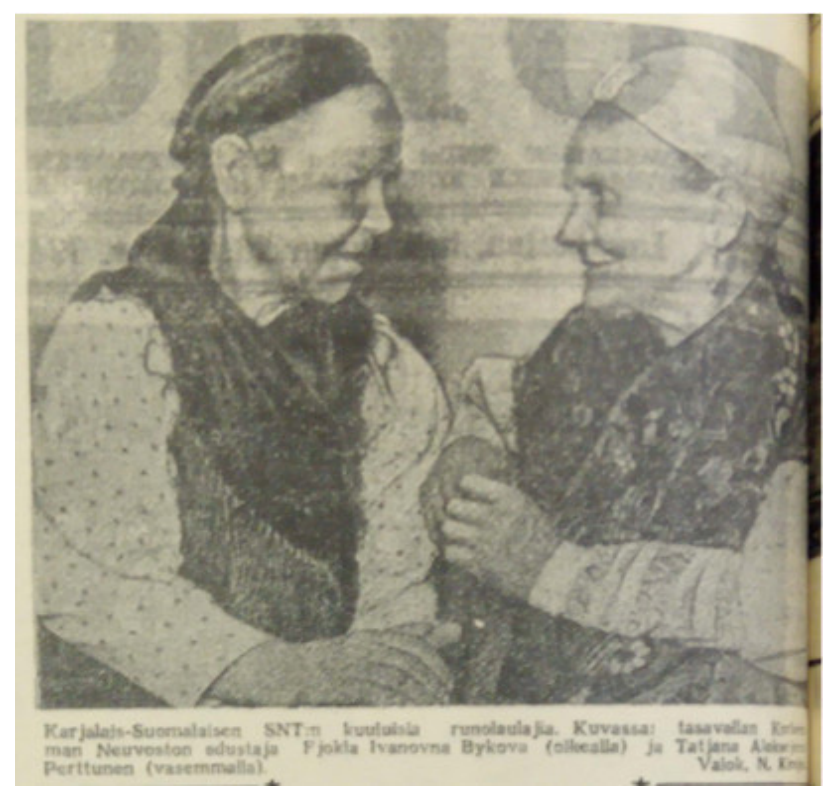

Kuva 2. Kuva runonlaulaja Tatjana Perttusesta (vas.) ja Fjokla Bykovasta Kalevalan toisen edition 100-vuotisjuhlallisuuksien uutisoinnin yhteydessä. Kuvateksti alkuperäislähteessä: "Karjalais-suomalaisen SNT:n kuuluisia runonlaulajia. Kuvassa: tasavallan Korkeimman Neuvoston edustaja Fjokla Ivanovna Bykova (oikealla) ja Tatjana Aleksejevna Perttunen (vasemmalla)." Totuus 26.2.1949. 
(KarTK F. 1 op. 2 kok. 27 säil.yks. 13 I. 45) seuraavasti: "Tätä runuo kun myö ukon kera luatima, mie se olen vähäsen muasterimpi, vain ukko pitäy muississah aina välillä sitä iellistä värssyö kuni mie tuumaicen ielläh, muuten mie voisin sekuo ta unohtaa sen mitä tuli ennen. Se ukon peä on niinkun varasto mihi mie panen valmehet värssyt." (KarTK F. 1 op. 2 kok. 27 säil.yks. 1 I. 10; Timonen 1984, 67).

Kuvauksen mukaan hän siis sepittää runoa lineaarisesti säe kerrallaan ja on värvännyt miehensäkin prosessiin muistamaan valmiit säkeet (ks. Tarkka 2005, 127-128). Kirjoitustaitoiset sepittäjät kirjasivat teoksensa ylös, kuten vasta aikuisiälä kirjoittamaan oppinut Maria Mihejeva, joka kylläkin piti perinteiset runot muistissaan (Timonen 1984, 78-79). Elina Timonen kuitenkin kuvaa, kuinka Maria Mihejeva sepitti runoa "Saapui sähkösahurit" (KarTK F. 1 op. 2 kok. 26 säil.yks. 1 I. 24). Sepitysprosessi on suorastaan haltioitunut, sellainen missä valmiit säkeet vain virtasivat Mihejevalta hänen saatuaan runon alun valmiiksi: "Siinä samassa syntyi runo edelleen kuin itsestään [...] tuntui siltä, että Maria oli suorastaan haltioissaan. Hänen poskillensa oli ilmestynyt punaa ja silmät loistivat nuorekkaina luomisinnossa." (Timonen 1984 , 82.) Runojen sepittäminen julkaisukelpoisiksi asti ei ilmeisesti ainakaan aina käynyt yhtä helposti. Palaka Kuikka kertoo kehottaneensa Mihejevaa 13.8.1949 muokkaamaan joitakin runoja vielä vähän valmiimmiksi, mihin tämä vastaa: "Ka sitä se miula poikaki aina sanou, jotta elä sie kiirehä heitä sinne työntyä, luaji paremmaksi. Ta kun ei häntä ole nyt tuas aikua istua niijen kera näin kesäaikah." (KarTK F. 1 op. 2 kok. 27 säil.yks. 1 I. 14.)

Folkloristi Palaka Kuikan kenttätyömuistiinpanoista vuodelta 1949 löytyy myös mielenkiintoinen maininta siitä, kuinka hän kehottaa Tatjana Perttusta laatimaan runon neuvostoliittolaisista sotasankareista, joista hän esimerkkinä kertoo Maria Melentjevasta ja Anna Lisitsinasta (KarTK F. 1 op. 2 kok. 27 säil.yks. 1 I. 15). Muutaman päivän kuluttua runo olikin valmis: Perttunen rakensi Melentjevan ja Litsinan dramaattisista vaiheista 98-säkeisen tuutulaulun, joka päättyy seuraaviin säkeisiin:

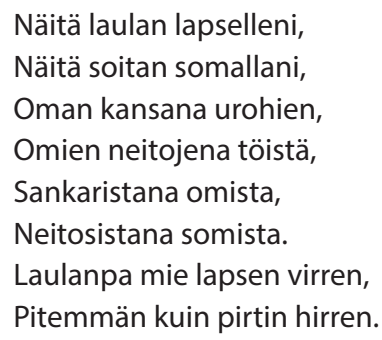

(KarTK F. 1 op. 2 kok. 27 säil.yks. 14 I. 28)

Perttunen kertoo samassa yhteydessä Kuikalle, että partisaanina toiminut ja suomalaisten ampuma Maria Melentjeva miellytti häntä aiheena, koska hän pystyi samastumaan siihen helposti: hänellä itselläänkin oli tuttavia, jotka olivat menettäneet henkensä Suuressa isänmaallisessa sodassa. Hän siis valikoi Kuikan kuvaamista aiheista sellaisen, johon hänellä oli omakohtaista kosketuspintaa, ja puki sen perinteen tarjoamaan tuutulaulun muotoon, joka kenties soveltui hänen mielestään nuoren naisen sankarillisuuden kuvaukseen esikuvaksi tulevalle sukupolvelle. Lopputulos oli siis tulosta yhteistyöstä kerääjän ja runonlaulajan kesken. 
Runonlaulajat tekivät runoja julkaistavaksi laajemmalle yleisölle kuin runokulttuuria tuntevalle välittömälle elinpiirilleen. Tämän vuoksi he saattoivat antaa runojensa lopullisen muodon suhteen päätösvaltaa julkaisujen toimituskunnalle. Esimerkiksi Jouki Hämäläinen kehottaa kirjeitse lähettämänsä runon saateviestissä Karjalan Tutkimusinstituutille 6.4.1951 (KarTK F. 1 op. 2 kok. 23 säil.yks. 100 I. 4) vastaanottajia korjaamaan Stalinia kuvaavassa runossaan mahdollisesti olevat virheet, jotta se olisi julkaisukelpoinen. Julkaisijat stilisoivat runoja epäilemättä pyytämättäkin. Runojen julkaisemiseen osallistuivat runonlaulajan ja kerääjän lisäksi siis myös julkaisun toimituskunta ja lopulta tämän työtä valvova sensoritaho (Plamper 2001; Ylikangas 2004, 405-408; ks. myös Kurki 2004).

Uusaiheisten runojen sepittäjien julkisuuskuva sidottiin vanhakantaiseen perinteeseen Kalevalalle keskeisen tradition ja sen elinpiirin kautta, ja toisaalta heitä luonnehdittiin sosialistisessa ideologiassa keskeisen vastukset ja kärsimykset voittaneen kiitollisen työläisen ideaalin kautta. Vakiintuneeseen tapaan kirjailija Antti Timonen kuvasi vielä vuonna 1968 heidän ilmaisuaan ja myös persooniaan jonkinlaisiksi naiiveiksi reliikeiksi muinaisuudesta (Timonen 1968, 426-427). Heidän hahmoissaan yhdistyy karjalaisten paikallinen ja etninen identiteetti sosialistiseen työn juhlaan. Luku- ja kirjoitustaito yleistyi Karjalassa neuvostohallinnon alaisuudessa nopeasti, mikä merkitsi monille runonlaulajille paitsi mahdollisuutta laajentaa helpommin maailmankuvaansa ja käsitystään sanallisen ilmaisun mahdollisuuksista, myös tuottaa ja säilyttää uutta runoutta ilman muistin rajallisuuden aiheuttamia vaikeuksia. Runojen päätyminen julkaisuihin ja niiden lopullinen muoto oli silti monesti monen eri instanssin toiminnan tulosta.

\section{Yhteenveto}

Neuvosto-Karjalassa todettiin kotoperäisen kirjallisuuden puute haitaksi 1920-luvun lopulla, ja vahvasti suomenkielisessä ympäristössä erottautuminen porvarillisesta Suomesta ja myös suomalaisesta kirjallisesta kulttuurista koettiin poliittisesti tärkeäksi. Suullinen perinne katsottiin mahdolliseksi malliksi kotoperäiselle kirjallisuudelle, ja kalevalamittaa käytettiinkin taiderunouden mittana. Mitta liittyi paitsi karjalaisuuteen, myös suomalaisen karelianismille rakentuneen nationalismin kommentointiin (Ahola 2020). Neuvostoliitossa folkloristit lunastivat 1930-luvulla yhteiskunnallisen relevanssinsa tuomalla esiin kansanperinteen potentiaalin väestön ajatusmaailmaan vaikuttamisessa, propagandassa. Tässä mielessä folklore sai samankaltaisen aseman kuin kirjallisuus sosialismin rakentamisessa. Ideologisesti oikeaoppisen kansanperinteen julkaisemisen kautta poliittinen hallinto saattoi vakuuttaa kansalle itselleen, että sen massat olivat sosialistisen järjestelmän ja hallinnon puolella, ja ideologisesti oikeaoppista kansanperinnettä pyrittiin juurruttamaan todelliseen käyttöön kansan ideologisen orientoitumisen ohjaamiseksi. Tämän toteuttamiseksi keskushallinto valjasti poliittisesti valveutuneet ja sitoutuneet tahot akateemisen tutkimuksen ja kirjallisuusliittojen piiristä yhteistyöhön paitsi keskenään, myös kansanperinteen taitajien kanssa.

Neuvosto-Karjalassa prosessi alkoi vuoden 1937 jälkeen. Kansalliseksi uusaiheisen perinteen muodoksi vakiintui kalevalamitta ja pohjoisessa runokulttuurissa tyypillinen kertova rakenne, jotka yhdessä määrittivät muodon sellaiseksi, jota tässä on kutsuttu "neuvostokalevalaiseksi." Runous oli runonlaulajien toteuttamaa ja tuottamaa, toimittajien ja kerääjien ohjaamana. Runonlaulajien ohjaamisen tavoitteet liittyivät paitsi heidän sepittämiensä runojen ideologiseen oikeaoppisuuteen, myös niiden ymmärrettävyyteen laajalle yleisölle kuitenkin niin, että runot olivat luettavissa perinteenmukaisiksi. Aiheiltaan ja tematiikaltaan 
runot liittyivät yleiseen neuvostoaikaiseen julkisen puhumisen tapaan, joskin usein runonlaulajien näkökulmasta, josta - osaksi perinteeseen liittyvän ilmaisutavan myötä - aiheiden käsittely on usein hyvin konkreettista ja maanläheistä. Runoissa siis yhdistyvät 1) runoilijayksilöiden kokemukset ja näkemykset (sekä omakohtaiset että opastajien kasvatuksen myötä muotoillut), 2) runoperinteen tarjoamat kielelliset resurssit ja myös sen aiheuttamat kielelliset rajoitukset sekä 3) laajemman neuvostoliittolaisen kirjallisuus- ja julkaisukontekstin edellytykset ja odotukset ja varsinkin runojen tuottajaportaan oletukset näistä odotuksista. Runonlaulajat muotoilivat tekstejään sekä ilmaisullisesti että sisällöllisesti suhteessa oletuksiinsa julkaisijoiden ja lukijoiden valmiuksista ja odotuksista.

Runoilijayksilötolivat paitsi perinnespesialisteja, myös neuvostokansalaisia. Heidän elämänsä kovuus vallankumousta edeltävänä aikana oli olennainen osa heidän henkilökuvaansa, ja sillä voi katsoa olleen huomattava vaikutus heidän runojensa vastaanottoon. Yhtäältä heissä henkilöityi karjalainen kulttuuri ja identiteetti, joiden jatkuvuuden edellytysten korostettiin parantuneen neuvostohallinnon aikana ja joiden elinvoimaisuutta neuvostokalevalaiset runotkin edustivat. Toisaalta taas heidän kärsimyksensä riistetyn luokan edustajina lisäsivät uskottavuutta heidän runoilijuuteensa massojen äänenä ja sitä myötä antoivat heidän runoilleen lisää painoarvoa. Poliittisesta ohjauksesta huolimatta ei voi ajatella, että laulajat olisivat omaksuneet neuvostoaiheiset sisällöt yksinomaan poliittisen ohjauksen välityksellä; sosialistisissa järjestelmissä yksilöiden suhde hallintoon on usein monitahoista ja epäselvää, ja valtasuhteet saattoivat vaihdella (Gerber ja Woods 1994, 25-37; Jones 2011, 203-204; Annus 2018, 14-15). Neuvostoyhteiskunnan jäsenenä oli luonnollista ilmaista yhteiskunnassa vallitsevien diskurssien mukaisia asioita.

Runonlaulajat käyttivät teoksissaan perinteen resursseja luovasti ja vaihtelevalla tavoin ja pyrkivät liikkumaan "perinteellisyyttä" merkitsevien piirteiden puitteissa ilmaistessaan sitä muuttuvaa kulttuurista todellisuutta, jossa he elivät. Perinteen tarjoama ilmaisukeinosto saattoi olla sen sisäistäneelle runonlaulajalle rikas kielimuoto, jolla tuoda esiin varsinaiselle perinteelle vieraitakin aihepiirejä (vrt. Leino 1975, 46-47). Myös Juri Sokolov kiinnitti huomiota siihen, että vaikka uusaiheiset runot muistuttavat vanhaa runoutta, ne ovat eritoten lyyriseltä laadultaan ja vapaalta rakenteeltaan niihin nähden "ylivoimaisia" (Sokolov 1966, 676-677).

Kalevalamittainen runous ja sittemmin neuvostokalevalainen runous esitettiin osaksi neuvostokarjalaista kotoperäistä kirjallista kulttuuria. Neuvostoliitossa käynnistynyt laajempi ohjelma ideologisesti oikeaoppisen kansanperinteen tuottamiseksi vaikutti neuvostokalevalaisen runouden sisältöihin luomalla kerääjien ja muiden opastajien kautta runonlaulajille oletuksia siitä, mitä heiltä odotettiin. Kirjallisuuden kentällä neuvostokalevalainen runous oli alisteinen samankaltaisille tuotantoprosesseille kuin kirjallisuus muutoinkin, ja lopullisiin julkaisuihin vaikuttivat monet eri instanssit, viime kädessä sensuuri ja vastaavat toimittajat. Runonlaulajien tästä prosessista saama palaute vaikutti epäilemättä myös siihen, millaisia tekstejä he loivat ja tarjosivat julkaistaviksi. Tämä vaikutti edelleen runojen yhdenmukaistumiseen 1950-luvulle tultaessa.

Oma kiinnostava kysymyksensä liittyy suomen kielen käyttöön neuvostokalevalaisen runouden julkaisukielenä. Se liittyi yleisemmin kansanperinteeseen ja Kalevalaan liittyviin käsityksiin ja niiden diskursiivisiin ilmauksiin, joissa neuvostokalevalainen runous oli osoitus Kalevalan pohjalla olevan runoperinteen elävyydestä ja jatkuvuudesta uudessa 
yhteiskuntajärjestyksessä, "uuden sosialistisen ihmisen" ilmaisutapana. Sellaisena neuvostokalevalainen runous oli yksi peruste esittää vaatimuksia Kalevalaan, Suomen porvariston omimaan kansaneepokseen, millä saatettiin ajatella olevan sodanjälkeisellä stalinistisella aikakaudella poliittistakin merkitystä suhteessa sodan hävinneeseen Suomeen. (Ks. Ahola 2020.)

Neuvostokalevalainen runous kasvoi kontekstissa, jossa perinteinen kulttuuri solmiutui ideologisesti aktiiviseen sosialistiseen rakennustyöhön. Runojen estetiikka viittaa näihin kahteen näennäisen vastakkaiseen todellisuuteen samanaikaisesti, jolloin se ei tee sitä kummankaan kohdalla täysin; teksteinä neuvostokalevalaiset runot siis edustavat ja ruumiillistavat sitä kahtalaisuutta ja monitulkintaisuutta, jota sosialistisessa järjestelmässä ja todellisuuskuvassa eläminen Neuvosto-Karjalassa merkitsi. Runojen ansiot eivät ole niinkään sosialistisen ideologian välittämisessä tai perinteisen ilmaisutavan soveltamisessa uusiin aiheisiin kuin sen runonlaulajien kokeman todellisuuden ilmaisemisessa, joka sijoittuu näiden kahden näkökulman väliin. Tämä todellisuus muodostui viime kädessä neuvostojärjestelmän enemmän tai vähemmän täsmällisistä odotuksista ja vaatimuksista kalevalamittaista runoperinnettä kohtaan sekä runonlaulajien kahtalaisesta positiosta neuvostokansalaisina ja runokulttuurinsa edustajina.

\section{Lähteet ja kirjallisuus}

\section{Arkistolähteet}

Kirjalliset lähteet

KarTK = Venäjän tiedeakatemian Karjalan tiedekeskuksen tieteellinen arkisto. Fond $n$ opis $n$ kokoelma $n$ säilytysyksikkö $n$ lehti $n=$ KarTK F. $n$ op. $n$ kok. $n$ säil.yks. $n$ I. $\mathrm{n}$

KarTK F. 1 op. 2 kok. 15 säil.yks. 1.

KarTK F. 1 op. 2 kok. 15 säil.yks. 2.

KarTKF. 1 op. 2 kok. 20 säil.yks.66I.352-353. Maura Hotejeva:"Itkuvirsi Leninin muistopäivänä". Kirjannut T. Ananina v. 1937.

KarTK F. 1 op. 2 kok. 20 säil.yks. 67 I. 354-356. Maura Hotejeva: "Itku Leninistä". Kirjannut T. Ananina 21.7.1937.

KarTK F. 1 op. 2 kok. 20 säil.yks. 68 I. 358-359. Maura Hotejeva: "Великий Ленин", kirjattu kyrillisin kirjaimin.

KarTK F. 1 op. 2 kok. 23 säil.yks. 55 I. 155. Jouki Hämäläinen: "Karjala". Allekirjoitus Jouki Hämäläinen.

KarTK F. 1 op. 2 kok. 23 säil.yks. 57 I. 158-161. "Heimoveljien tulo Karjalaan". Allekirjoitus Jouki Hämäläinen.

KarTK F. 1 op. 2 kok. 23 säil.yks. 60 I. 166. Jouki Hämäläinen. Ei otsikkoa, teksti alkaa "Jopa myö vuotta viisi". Vuosiluku "v. 1946". Ei allekirjoitusta.

KarTK F. 1 op. 2 kok. 23 säil.yks. 60a I. 217-218. Jouki Hämäläinen: teksti alkaa "Kuuluipa jyrinä julma". Saatu kirjeitse 20.3.1946. 
KarTK F. 1 op. 2 kok. 23 säil.yks. 100 I. 4. Jouki Hämäläinen: Kirje, päivätty Uhtualla 6.4.1951. Allekirjoitus Jouki Hämäläinen.

KarTK F. 1 op. 2 kok. 24 säil.yks. 28a I. 113. "Tatjana Perttuselta." Kirjannut Viktor Jevsejev 1949.

KarTK F. 1 op. 2 kok. 25 säil.yks. 41 I. 109. Tatjana Perttunen: "Elämäkerta (itsensä kertomana)". Kirjannut Eini Gran 9.4.1941.

KarTK F. 1 op. 2 kok. 26 säil.yks. 1 I. 24. Maria Mihejeva: teksti alkaa "Kasvau puut Karjalassa." Kirjannut Elina Huttari 8.7.1948 Uhtualla.

KarTK F. 1 op. 2 kok. 27 säil.yks. 1. Palaka Kuikan kenttämuistiinpanot elokuulta 1949.

KarTK F. 1 op. 2 kok. 27 säil.yks. 13 I. 45. Tatjana Perttunen: teksti alkaa "Eli nuori Väinö-poika." Kirjannut Palaka Kuikka 8.8.1949.

KarTK F. 1 op. 2 kok. 27 säil.yks. 14 I. 28. Tatjana Perttunen: teksti alkaa "Miepä laulan lapsellani". Kirjannut Palaka Kuikka 13.8.1949.

SKS KRA = Suomalaisen Kirjallisuuden Seura, Perinteen ja nykykulttuurin kokoelma.

SKS KRA 290. Tuomaala, Väinö 290. 1941. Syvärin rintama.

Äänitteet

KarTK äänit. = Venäjän Tiedeakatemian Karjalan tiedekeskuksen äänitearkisto. Kokoelma $n$ / säilytysyksikkö $n=$ KarTK äänit. Kok. $n$ / säil.yks. $n$

KarTK äänit. Kok. 14 / säil.yks. 1. Tatjana Perttunen: laulu alkaa "Kelpo miehen kellitellä". Äänittänyt Viktor Jevsejev.

KarTK äänit. Kok. 14 / säil.yks. 14. Maria Mihejeva: laulu alkaa "Kiitos suuri johtajamme". Äänittänyt Viktor Jevsejev.

\section{Julkaistut aineistolähteet}

Fokin, I. 1937. "Кюля эннен и нӱгӧй." Punainen Karjala 12.12.1937.

Haurinen, Kiril. 1941. "Runo Kemin tiestä." Punalippu 5/1941: 34.

Haurinen, Kiril. 1941. "Vanha aika." Punalippu 5/1941: 33.

Hotejeva, Maura. 1941. "Itkuvirsi Leninille" Punalippu 1/1941: 117.

Hämäläinen, Jouki. 1953. "Stalin elää ikuisesti." Punalippu 1/1953: 15-16.

Johansson, Oskar. 1930. "Väkevien voimalla." Puna-Kantele 2/1930: 10.

Kondratjev, F. 1937. "Miten elin ennen ja miten minä elän nyt." Punainen Karjala 18.12.1937.

Kyllönen, Joel. 1929. "Kyläisen kanteleen sointuja." Puna-Kantele 4/1929: 16.

Mihejeva, Maria. 1941. "Runo Stalinista." Punalippu 5/1941: 32.

Mihejeva, Maria. 1947. "Jopa Saksakin surevi..." Punalippu 3/1947: 101-102.

Mihejeva, Maria. 1947. "Pian siirtyy synkkä aika." Punalippu 3/1947: 103.

Mihejeva, Maria. 1949. "Kalevala 100-vuotias." Totuus 25.2.1949.

Mihejeva, Maria. 1964. "Laulan lokakuusta" Punalippu 4/1964: 85. 
Minin, E. I. 1945. "Uusi sampo." Totuus 28.2.1945.

Nikiforova, Anastasija. 1947. "Sovetskoi muan suuri seppy." Punalippu 3/1947: 99-100.

Pavkova, M. F. 1939. "Вирзы Ленинах нӓх." Karelija 1/1939: 39.

Perttunen, Tatjana. 1941. "Laulu." Punalippu 5/1941: 39.

Remsu, Maria. 1937. "Matkalaulu." Punainen Karjala 11.3.1937.

Rjabinin-Andrejev, Petr. 1947. "Bylina marsalkka Rokossovskista." Suom. V. Ervasti. Punalippu 3/1947: 104-106.

Rusko, Ragnar. 1928. "Kenpä virren viertäjäksi?" Soihtu 6/1928: 1.

Rusko, Ragnar. 1929. "Porvoon 'valloitus."' Soihtu 1/1929: 13.

Rusko, Ragnar. 1930. "Karjala (Runo 10-vuotiaalle)." Soihtu 7-8/1930: 4.

SKVR = Suomen Kansan Vanhat Runot I-XV. Helsinki: Suomalaisen Kirjallisuuden Seura, 1908-1997. http://skvr.fi/

\section{Kirjallisuus}

Ahola, Joonas. 2020. "'Kalevala - kansan luomistyön ihana perintö': Kalevalaan ja kansanperinteeseen liittyvät diskurssit neuvostokarjalaisessa suomenkielisessä lehdistössä 1928-1958." Elore 27(2): 4-29. https://doi.org/10.30666/elore.96105

Alin, Esa. 1984. 'Mitä itet, uuši purši, uuši moottori mökiset?' Neuvosto-Karjalan uusaiheisesta runosta. S 321. Filosofian kandidaatin tutkielma. Helsingin yliopisto.

Alin, Esa. 1988. "'Hiihti armas Antikainen'. Neuvosto-Karjalan uusaiheisesta epiikasta." Teoksessa Monikasvoinen folklore, toimittaneet Irma-Riitta Järvinen, Jyrki Pöysä ja Sinikka Vakimo, 49-64. Helsingin yliopiston kansanrunoustieteen laitos.

Annus, Epp. 2018. Soviet Postcolonial Studies: A View from the Western Borderlands. Routledge Series on Russian and East European Studies 112. London \& New York: Routledge.

Baldano, Marina N. ja Pavel K. Varnavskiy. 2016. «'Национальная по форме, социалистическая по содержанию': бурятская нация в советском идеологическом дискурсе." Вестник Томского государственного университета 412: 40-49.

Belovanova, A. ja Razumova, A. (toim.) 1947. Фольклор Советской Карелии. Петрозаводск: Государственное издательство Карело-Финской ССР.

E. P. 1934. "Muistelmia neuvostokirjailijain edustajakokouksesta." Rintama 20/1934: 3-7.

Gerber, Marcy ja Roger Woods (toim.) 1994. Understanding the past, managing the future: the integration of the five new Länder into the Federal Republic of Germany: selected papers from the eighteenth New Hampshire Symposium. Lanham, MD: University Press of America.

Gran, Eini. 1947. "Neuvostovallan vuosina syntynyt kansanrunous." Punalippu 5/1947: 174-182.

Gran, Eini. 1954. "Katsaus runonlaulajien luovaan työhön." Punalippu 3/1954: 126-128.

Grenoble, Leonore A. 2003. Language Policy in the Soviet Union. Dordrecht: Kluwer Academic Publishers. 
Herzog, Philipp. 2010."'National in Form and Socialist in Content' or Rather 'Socialist in Form and National in Content'?: The 'Amateur Art System' and the Cultivation of 'Folk Art' in Soviet Estonia." Narodna umjetnost 47(1): 115-140.

Howell, Dana Prescott. 2015. The Development of Soviet Folkloristics. London: Routledge.

J. V. 1935. "Otteita Kalevalasta." Rintama 2/1935: 18-22.

Jaakkola, Nikolai. 1949. "Karjalais-suomalainen neuvostorunous ja Kalevala." Punalippu 10/1949: 37-46.

Jalava, Aulikki. 1990. Kansallisuus kadoksissa: Neuvosto-Karjalan suomenkielisen epiikan kehitys. Väitöskirja. Helsinki: Suomalaisen Kirjallisuuden Seura.

Jevsejev, Viktor. 1940. Сампо: сборник карело-финских рун. Петрозаводск: Госиздат карело-финской ССР.

Jevsejev, Viktor. 1941. "Lenin ja kansanrunous." Punalippu 1/1941: 115-118.

Jevsejev, Viktor. 1947. "Kansanrunouden kehityksestä Neuvostomaan oloissa." Punalippu 3/1947: 97-98.

Jevsejev, Viktor (toim.) 1950. Карельские зпические песни. Москва и Ленинград: Издательство академии наук СССР.

Jevsejev, Viktor. 1953. "Karjalais-suomalainen kansanrunous J. V. Stalinista." Punalippu 1/1953: 64-71.

Jevsejev, Viktor. 1960. "Lenin karjalaisessa kansanrunoudessa." Punalippu 2/1960: 105-108.

Jones, Sara. 2011. Complicity, Censorship and Criticism: Negotiating Space in the GDR Literary Sphere. Berlin \& New York: Walter de Gruyter.

Kalkun, Andreas ja Janika Oras. 2018. "'Stalin is a wise man, Lenin was a little bird.'On Creating Soviet Folklore in the Seto Region during the Stalin Era." Res Musica 10/2018: 41-62.

Kangaspuro, Markku. 2000. Neuvosto-Karjalan taistelu itsehallinnosta: nationalismi ja suomalaiset punaisen Neuvostoliiton vallankäytössä 1920-1939. Helsinki: Suomalaisen Kirjallisuuden Seura.

Kaukonen, Väinö. 1980. "Vanhasta runonlaulusta uuteen runoon." Teoksessa Kertojat ja kuulijat, Kalevalaseuran vuosikirja 60, toimittanut Pekka Laaksonen, 222-226. Helsinki: Suomalaisen Kirjallisuuden Seura. Kronhaus, Aleksander. 1949. "Tatjana Perttunen." Totuus 23.2.1949.

Kruhse, Pauli \& Antero Uitto. 2008. Suomea rajan takana 1918-1944: suomenkielisen neuvostokirjallisuuden bibliografia. Helsinki: BTJ.

Kurki, Tuulikki. 2004. "Kansanomaisuus, kirjallisuus ja merkityskytkennät NeuvostoKarjalassa." Elore 2/2004. https://doi.org/10.30666/elore.78456

Kurki, Tuulikki. 2006. "Kirjoitettu ja luettu kylä Neuvosto-Karjalan kirjallisuudessa."Teoksessa Paikka: eletty, kuviteltu, kerrottu. Kalevalaseuran vuosikirja 85, toimittaneet Seppo Knuuttila, Pekka Laaksonen ja Ulla Piela, 252-270. Helsinki: Suomalaisen Kirjallisuuden Seura.

Kurki, Tuulikki. 2018. Rajan kirjailijat: Venäjän Karjalan suomenkieliset kirjailijat tilan ja identiteetin kirjoittajina. Helsinki: Suomalaisen Kirjallisuuden Seura.

Kuusinen, Otto Wille. 1949. Kalevalan runoutta. Valikoima karjalais-suomalaisen kansaneepoksen runoja. Laadittu Elias Lönnrotin toimittaman Kalevalan pohjalla. Petroskoi: Karjalais-suomalaisen SNT:n valtion kustannusliike. 
Leino, Pentti. 1975. "Äidinkieli ja vieras kieli: rahvaanrunouden metriikkaa." Teoksessa Wäinämöisen Weljenpojat, Kalevalaseuran vuosikirja 55, toimittaneet Jukka Kukkonen ja Hannes Sihvo, 26-48. Porvoo ja Helsinki: WSOY.

Mihelj, Sabina ja Reana Senjkovic. 2010. "Introduction: Socialist Popular Cultures between Folklore and Nationalism." Narodna umjetnost 47(1): 111-114.

Mikkonen, Simo ja Pekka Suutari. 2006. "Karjalan taidepäivät Leningradissa maaliskuussa 1937 - käännekohta Karjalan musiikin historiassa." Teoksessa Etnomusikologian vuosikirja 18, toimittanut Markus Mantere, 157-183. Suomen etnomusikologinen seura.

Miller, Frank J. 1980. "The Image of Stalin in Soviet Russian Folklore." The Russian Review 39(1): 50-67.

Miller, Frank J. 1990. Folklore for Stalin: Russian Folklore and Pseudofolklore of the Stalin Era. New York \& London: M. E. Sharpe.

Mišin, Armas. 1989. Neuvosto-Karjalan kirjailijat: Hakuteos. Petroskoi: "Karjala".

Oinas, Felix J. 1973. “Folklore and Politics in the Soviet Union." Slavic Review 32(1): 45-58.

Olson, Laura J. 2004. Performing Russia: Folk Revival and Russian Identity. New York: Routledge Curzon.

Panchenko, Alexander. 2005. "The Cult of Lenin and 'Soviet Folklore.' Folklorica 10(1): 18-38.

Panchenko, Alexander. 2012. "Introduction: Social Constructionism and the History of Russian Folkloristics." Teoksessa A Companion to Folklore, toimittaneet Regina F. Bendix ja Galit Hasan-Rokem, 426-441. Oxford: Blackwell Publishing.

Plamper, Jan. 2001. "Abolishing Ambiguity: Soviet Censorship Practices in the 1930s." The Russian Review 60(4): 526-544.

Punalippu 1/1941. "Karjalan SSNT:n neuvostokirjailijain ensimmäinen edustajakokous." 109-112.

Rugojev, Jaakko. 1958. "Karjalaiset runonlaulajamme." Punalippu 6/1958: 111-119.

Rugojev, Jaakko. 1959. (toim.) Laulu uudesta sammosta: Runoja. Petroskoi: Karjalan ASNT:n Valtion Kustannusliike.

Rugojev, Jaakko. 1965. "Kalevalan runoperinne elää." Punalippu 4/1965: 93-100.

Salo, Viktor. 1931. "Uusi elämä uusissa laulun sepitelmissä." Punakantele 5/1931.

Savolainen, Yrjö. 1934. " Sirpaleita inkeriläisestä kansanrunoudesta." Rintama 18/1934: 26-28.

Shelestyuk, Elena. 2019. "National in Form, Socialist in Content: USSR National and Language Policies in the Early Period." SHS Web of Conferences 69(157): 00104. https:// doi.org/10.1051/shsconf/20196900104 (Luettu 14.4.2021.)

Sirola, Yrjö. 1935. "Kalevalan 100-vuotismuisto." Kevätvyöry 7/1935: 109-124.

Slezkine, Yuri. 1994. "The USSR as a Communal Apartment, or How a Socialist State Promoted Ethnic Particularism." Slavic Review 53(2): 414-452.

Sokolov, Yuri M. 1966. Russian Folklore. Kääntänyt Catherine Ruth Smith. Hatboro, Pennsylvania: Folklore Associates.

Stepanova, Eila. 2014. Seesjärveläisten itkijöiden rekisterit: Tutkimus äänellä itkemisen käytänteistä, teemoista ja käsitteistä. Kultaneito XIV. Joensuu: Suomen kansatietouden tutkijain seura. 
Sykiäinen, Josef. 1940. "Kirjallisuusliikkeen tehtävistä Karjalais-suomalaisessa SNT:ssä." Kommunisti 6/1940: 7-17.

Tarkka, Lotte. 2005. Rajarahvaan laulu: tutkimus Vuokkiniemen kalevalamittaisesta runokulttuurista 1821-1921. Helsinki: Suomalaisen Kirjallisuuden Seura.

Thurston, Robert W. 1991. "Social Dimensions of Stalinist Rule: Humor and Terror in the USSR, 1935-1941." Journal of Social History 24: 541-562.

Timonen, Antti. 1968. "Kalevala ja Neuvosto-Karjalan kirjallisuus." Teoksessa Kalevalaseuran vuosikirja 48, 423-433. Porvoo \& Helsinki: WSOY.

Timonen, Elina. 1949. "Kalevalan laulumailla." Punalippu 10/1949: 28-36.

Timonen, Elina. 1984. Ei mahti maahan jouda: Lähikuvia runonlaulajista. Petroskoi: Karjala-kustantamo.

Tolz, Vera. 2002. "'Cultural Bosses' as Patrons and Clients: The Functioning of the Soviet Creative Unions in the Postwar Period." Contemporary European History 11(1): 87-105.

Torikka, Marja. 2003. "Karjala." Kielikello 1/2003. https://www.kielikello.fi/-/karjala (Luettu 13.4.2021)

Totuus 23.2.1949. "Runonlaulaja Ivan Konevalov"

Vinogradov, N. 1935. "Karjalaisia runonlaulajia." Rintama 2/1935: 7-9.

Virtanen, Jalmari. 1956. Valittuja runoja. Petroskoi: Karjalan ASNT:n valtion kustannusliike.

Ylikangas, Mikko. 2004. Rivit suoriksi! Kaunokirjallisuuden poliittinen valvonta NeuvostoKarjalassa 1917-1940. Väitöskirja. Helsinki: Aleksanteri-instituutti.

Zemtsovsky, Izaly ja Alma Kunanbaeva. 1997. "Communism and Folklore."Teoksessa Folklore and Traditional Music in the Former Soviet Union and Eastern Europe, toimittanut James Porter, 3-23. Los Angeles: Department of Ethnomusicology, UCLA.

Zezina, Maria. 1994. "Crisis in the Union of Soviet Writers in the Early 1950s." Europe-Asia Studies 46(4): 649-661.

Ziolkowski, Margaret. 2013. Soviet Heroic Poetry in Context: Folklore or Fakelore. Plymouth: University of Delaware Press.

Joonas Ahola (FT) on folkloristiikan tutkija, joka toteuttaa Kalevalaseuran tukemana tutkimushanketta "Neuvostokalevalainen runous: Rahvaanrunon muoto, sisältö ja merkitys Stalinin ajan Neuvosto-Karjalassa". Ahola kiittää Eloren toimitusta sekä anonyymejä arvioijia hyvistä neuvoista tekstin viimeistelyksi. 